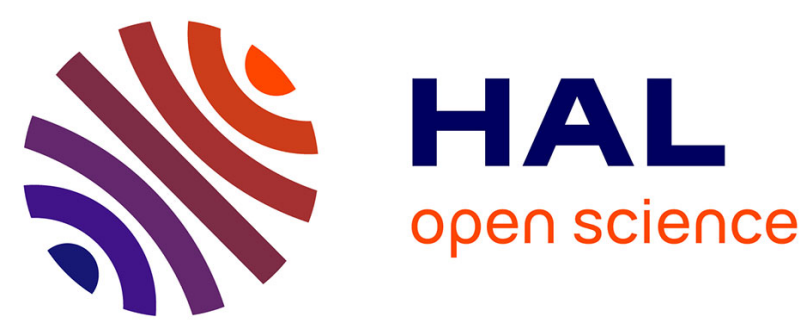

\title{
A multidisciplinary study on the emplacement mechanism of the Qingyang-Jiuhua Massif in Southeast China and its tectonic bearings. Part I: structural geology, AMS and paleomagnetism
}

Wei Wei, Yan Chen, Michel Faure, Y.H. Shi, Guillaume Martelet, Q.L. Hou, Wei Lin, Nicole Le Breton, Q.C. Wang

\section{To cite this version:}

Wei Wei, Yan Chen, Michel Faure, Y.H. Shi, Guillaume Martelet, et al.. A multidisciplinary study on the emplacement mechanism of the Qingyang-Jiuhua Massif in Southeast China and its tectonic bearings. Part I: structural geology, AMS and paleomagnetism. Journal of Southeast Asian earth sciences, 2014, 86, pp.76-93. 10.1016/j.jseaes.2013.06.003 . insu-00834118

\section{HAL Id: insu-00834118 \\ https://hal-insu.archives-ouvertes.fr/insu-00834118}

Submitted on 14 Jun 2013

HAL is a multi-disciplinary open access archive for the deposit and dissemination of scientific research documents, whether they are published or not. The documents may come from teaching and research institutions in France or abroad, or from public or private research centers.
L'archive ouverte pluridisciplinaire HAL, est destinée au dépôt et à la diffusion de documents scientifiques de niveau recherche, publiés ou non, émanant des établissements d'enseignement et de recherche français ou étrangers, des laboratoires publics ou privés. 


\title{
A multidisciplinary study on the emplacement mechanism of the Qingyang-Jiuhua Massif in Southeast China and its tectonic bearings. Part I: structural geology, AMS and paleomagnetism
}

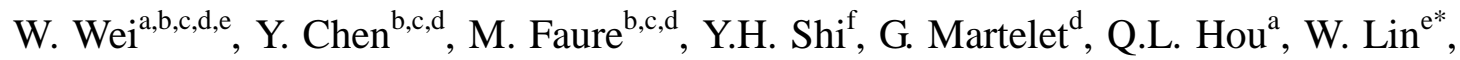 \\ N. Le Breton ${ }^{\text {b,c,d }}$, Q.C. Wang ${ }^{\mathrm{e}}$ \\ ${ }^{a}$ University of Chinese Academy of Sciences, Beijing 100049, China \\ ${ }^{\mathrm{b}}$ Univ d'Orléans, ISTO, UMR 7327, 45071, Orléans, France \\ ${ }^{\mathrm{c}}$ CNRS/INSU, ISTO, UMR 7327, 45071 Orléans, France \\ ${ }^{\mathrm{d}}$ BRGM, ISTO, UMR 7327, BP 36009, 45060 Orléans, France \\ ${ }^{\mathrm{e}}$ Institute of Geology and Geophysics, Chinese Academy of Sciences, Beijing 100029, China \\ ${ }^{\mathrm{f}}$ Hefei University of Technology, Hefei 230009, China
}

*Corresponding author: linwei@mail.iggcas.ac.cn

\begin{abstract}
During the Cretaceous, the South China Block (SCB) experienced a widely distributed extensional event including numerous plutons emplacement and basin opening. Investigations on the tectonic regime coeval with pluton emplacement, and emplacement mechanism of the pluton remain relatively rare in the SCB. In order to address these questions, a multidisciplinary approach, including field structural and petrographic observations, anisotropy magnetic susceptibility (AMS) and paleomagnetic analyses, was carried out on the Qingyang-Jiuhua granitic massif which intrudes into the Lower Yangtze fold belt in the northeastern part of SCB. The Qingyang-Jiuhua massif is composed of the granodioritic Qingyang and monzogranitic Jiuhua plutons dated by zircon U-Pb method at ca. $142 \mathrm{Ma}$, and ca. 131 Ma, respectively. Our structural observations show that the intrusion of the Qingyang-Jiuhua massif does not modify the fold strike. A weak ductile deformation
\end{abstract}


of the country rocks and granitoid can be only observed in the boundary zone with limited contact metamorphism. In the contact aureole of the massif, the foliation follows the pluton contour, and the mineral lineation is rare. When present, it exhibits a down-dip attitude. Field and microstructural observations indicate isotropic magmatic textures in most parts of the massif. The AMS analysis of 93 sites reveals weak values for the anisotropy degree $\left(\mathrm{P}_{\mathrm{J}}<1.2\right)$ and oblate magnetic fabric dominance $(\mathrm{T}>0)$ for most of the measured samples. Two principal foliation patterns are identified: horizontal foliations in the center of the plutons, and vertical foliations on the boundaries. Magnetic lineation strike is largely scattered, and weakly inclined at the scale of the entire massif. The paleomagnetic investigations indicate that (a) the younger Jiuhua pluton did not produce a remagnetization in the older Qingyang pluton, (b) no relative movement can be observed between these two plutons, (c) the entire massif did not experience any important relative movement with respect to South China, considering the paleomagnetic uncertainties. Integrating the newly obtained results with previous observations, our study favors a permissive emplacement mechanism for the two plutons, i.e. vertical magma intrusion into an opening space controlled by the NW-SE brittle stretching of the upper crust, which is in agreement with a weak extensional regional tectonic framework of the SCB.

\section{Keywords}

South China Block; Pluton emplacement mechanism; Anisotropy of Magnetic Susceptibility; Paleomagnetism; Cretaceous tectonic extension. 


\section{Introduction:}

The Late Mesozoic geology of South China Block (SCB) is featured by a large number of graben or half-graben basins coupled with numerous plutons and related ore deposits (Gilder et al., 1991; Goodell et al., 1991; Zhou et al., 2006; Li et al., 2010a; Mao et al., 2011). The plutons and the adjacent contemporary basins are often connected by normal faults (Shu et al., 2009). Besides the plutons and basins, many other features, such as bimodal volcanic rocks, widely distributed dyke swarms, and development of normal faults systems, also argue for an extensional tectonic regime during the Late Mesozoic (Zhao et al., 2004; Zhou et al., 2006; Yu et al., 2007). Numerous geochronologic and geochemical studies have been conducted to document the source and evolution of the Mesozoic magmatism (Liu et al., 2012; Wu et al., 2012). Presently, it is widely accepted that the Late Mesozoic volcanic rocks in SCB shows an obvious magmatic arc affinity (Zhou et al., 2006 and references therein), and the plutons have a mixed provenance containing juvenile mantle material to some extent (Zhao et al., 2004; Yu et al., 2005; Xu et al., 2010). Moreover, the age of the plutonism reveals a coastward polarity (Zhou and Li, 2000; Li and Li, 2007). These facts were synthesized into the several speculative and incompatible geodynamic models, considering an increase of the subduction angle of the Paleopacific plate (Zhou and $\mathrm{Li}, 2000$ ) and a retreat of the Paleopacific slab (Li and Li, 2007). Moreover, it is worth to note that an NW-SE striking granitoid belt of ca. $400 \mathrm{~km}$ in length and $100 \mathrm{~km}$ in width was developed from $150 \mathrm{Ma}$ to $120 \mathrm{Ma}$, without any coastward 
polarity, in the lower Yangtze area in the northeast part of the SCB (Ling et al., 2009; Wu et al., 2012). Due to its variable composition of I-type, A-type granitoids and adakites, this belt is controversially interpreted as a result of Ocean Ridge Subduction (Sun et al., 2007; Ling et al., 2009) or a collapse of thickened crust (Zhang et al., 2008).

To better understand the geodynamic context of this extensional event, the assessment of the contemporary regional tectonics, and the mechanisms of pluton emplacement are also crucial. Although the geochemistry data is abundant in the Lower Yangtze area, the detailed structural analyses, such as structural observations to recognize the different scales of deformation, and extension direction, are still rare. Available regional deformation data in this area are derived from several scattered locations with ductile deformation and the regional extension direction are still controversial (Lin et al., 2000; Faure et al., 2003; Zhu et al., 2010a).

Among the rare existing structural studies, the Late Mesozoic extensional regime of SCB is the main feature for some authors (Gilder et al., 1991; Faure et al., 1996, 2003; Zhou et al., 2006; Shu et al., 2009), while the importance of a Late Mesozoic strike-slip regime has been emphasized by others (Xu et al., 1987; Gilder et al., 1996; Li et al., 2001). A sinistral transcurrent faulting during the Middle to Late Cretaceous is reported along the Tan-Lu fault (Mercier et al., 2007), and also in the SE coastal region of SCB (Wang and Lu, 2000).

In the present state of knowledge, structural studies on pluton emplacement and their bearings on the interpretation of regional tectonics are not available in the study 
area. In this study we choose the Qingyang-Jiuhua massif in the central part of the Lower Yangtze area as target to answer following questions: 1) What is the tectonic regime during the emplacement of this massif at ca. $140 \mathrm{Ma}-130 \mathrm{Ma}$ 2) Is there an obvious strike-slip regime after the crystallization of this massif? 3) What is the emplacement mechanism of this massif, and 4) Is there a relationship between the emplacement mechanism and the regional tectonic regime? A multidisciplinary approach has been applied in this study emphasizing i) the deformation of the granitic massif and its country rock at the micro, macro and regional scales, ii) the anisotropy of magnetic susceptibility (AMS) fabrics, and iii) the paleomagnetic analysis. Integrating newly obtained data with previous ones, the emplacement mechanism of the massif, and their relationship with the regional tectonic framework are discussed.

\section{Geological setting}

\subsection{Geologic framework of the Lower Yangtze area}

The Lower Yangtze area is located in the southeast of China and can be divided into three parts: the Dabie-Sulu massif in the north, the lower Yangtze fold belt in the middle, and the Jiangnan orogenic belt in the south (Fig. 1).

The Dabie-Sulu massif, separating the North China Craton from the Lower Yangtze fold belt, was well studied during last 3 decades because of its ultra high pressure metamorphism (Cong and Wang, 1999). This massif was formed by the Paleozoic collision between the North China and South China Blocks (Mattauer et al., 1985; Faure et al., 1999, 2003), followed by a Middle Triassic intracontinental subduction 
(Faure et al., 2008). During the Early Cretaceous, a migmatitic dome characterized by an NW-SE maximum stretching direction developed in the Dabie area (Lin et al., 2007). Several syn-kinematic granitoid plutons intruded into this dome (Hacker et al., 1998). Lastly, the eastern border of the Dabie dome is represented by the Tanlu normal fault, along which half-graben basins were filled by the Late Cretaceous continental red beds (Mercier et al., 2007).

The lower Yangtze fold belt is composed of sandstone, siltstone, mudstone and carbonate series, deposited from Neoproterozoic (Sinian) to Triassic (AHBGMR, 1987). During the Middle Triassic, the main body of these marine sedimentary rocks were folded and thrust to the SE (Schmid et al., 1999) while in the southern part of this belt, folds and thrusts may be due to the activity of the Jiangnan belt during this period (Li et al., 2010b). Upper Triassic conglomerate and sandstone unconformably deposited upon the older series (Shu et al., 2009). In the Jurassic time, the deposits are predominantly terrigeneous, volcanic and volcano-clastic. A Late Jurassic unconformity argues for a tectonic event (Yang et al., 2011). Since the Early Cretaceous, the extensional tectonic regime predominates in the lower Yangtze fold belt, as shown by the formation of continental red bed basins, and the emplacement of granitic plutons, including the Qingyang-Jiuhua massif investigated in this study (Fig. 1; Mercier et al., 2007; Shu et al., 2007, 2009; Zhu et al., 2010b).

The Jiangnan orogenic belt is a Neoproterozoic collision belt, where several ophiolitic masses are recognized (e.g. Shu et al., 2006). During the Early Paleozoic, an E-W fault system indicating an N-S shortening developed (Yu et al., 2007). In the 
Cretaceous, NE striking normal faults, are believed to control the Late Mesozoic red bed basin opening, and granitic pluton emplacement (Yu et al., 2007).

\subsection{Qingyang-Jiuhua massif}

The Qingyang-Jiuhua massif, located in the southern part of Anhui Province, Southeast China, is one of Late Mesozoic granitic massifs intruding into the Lower Yangtze fold belt. The massif crops out approximately on $\sim 750 \mathrm{~km}^{2}$ (Xu et al., 2010; Wu et al., 2012;). Lithologically, this massif is divided into the Qingyang pluton and the Jiuhua pluton (Fig. 2). The Qingyang pluton, consisting of 4 subplutons, is formed mainly by granodiorite with a diorite rim on its northeastern boundary. Lithologically, the Jiuhua pluton is divided into an ENE-WSW elongated monzogranitic facies, to the east, and a N-S striking K-feldspar granite to the west.

Several dating have been carried out on three facies by the U-Pb zircon method. The granodiorite of the Qingyang pluton is dated at $144.8 \pm 0.7 \mathrm{Ma}$ (Chen et al., 2005), $140 \pm 1.1 \mathrm{Ma}$ (Xu et al., 2010) and $139.4 \pm 1.8$ to $142.0 \pm 1.0 \mathrm{Ma}$ (Wu et al., 2012), the monzogranite of the Jiuhua pluton at $133.2 \pm 1.3 \mathrm{Ma}$ (Xu et al., 2010) and 130.3 \pm 1.8 to 131.0 $\pm 2.6 \mathrm{Ma}$ (Wu et al., 2012). The K-feldspar granite of the Jiuhua pluton is dated by zircon and monazite at $127 \pm 1.6 \mathrm{Ma}$ and $129 \pm 10 \mathrm{Ma}$, respectively (Xu et al., 2010). So the Qingyang-Jiuhua massif is probably formed by two magmatic events within about 10Ma (Wu et al., 2012). Geologic investigations have also indicated that the Jiuhua pluton intrudes the Qingyang pluton, and then, the whole massif is intruded by NE-SW or N-S microgranite dykes (Fig. 2; AHBGMR, 1987). 
The Sm-Nd isotopic analyses show that the isotopic characteristics, and the $\mathrm{Nd}$ model age of granitoid near the Jiangnan orogenic belt, including the Qingyang-Jiuhua massif, are very similar to the surrounding Proterozoic metamorphic rocks (Chen et al., 1993). It is therefore argued that these granitoids originated from crustal melting without significant input of mantle material (Chen et al., 1993). The crustal anatexis is confirmed by the occurrence of inherited Archean zircons (Xu et al., 2010). The trace elements geochemistry suggests a magmatic arc affinity similar to the arc magmatism developed in the southeastern coast of China. The petrological, geochronological and geochemical features argue that the Qingyang-Jiuhua massif was also related to the Late Mesozoic Paleo-Pacific subduction (Xu et al., 2010).

\section{Structural analysis of the Qingyang-Jiuhua massif}

\subsection{Macroscopic fabrics in granite and contact metamorphic rocks}

The rock forming minerals of the Qingyang granodiorite are mainly quartz, K-feldspar, plagioclase, biotite and amphibole. The Jiuhua monzogranite consists of quartz, red K-feldspar, plagioclase and biotite. In both rocks, K-feldspar occurs as cm-sized megacrysts within an mm-sized matrix. Microgranite dykes are mainly composed of K-feldspar megacrysts with a minor amount of quartz and biotite.

Based on our field observation, the Qingyang and Jiuhua granitoids appear as isotropic rocks (Fig. 3a). The main parts of these two plutons are undeformed, the plagioclase, K-feldspar and quartz have euhedral to sub euhedral habits. The platy minerals, such as biotite, and needle minerals, such as amphibole, are randomly 
distributed without any preferred orientation. Deformation structures occur only on the boundary of the massif. In particular, along the northeastern boundary of the massif, biotite and amphibole form a well-developed preferred orientation with an N160E E65, and N20E E55 foliation in locations X(1)and (8. respectively (Fig. 2). In location 8. the granite foliation is subparallel both to the strike of the granite-host rock boundary and the foliation (N20E 90) measured in the adjacent marble in the metamorphic aureole. On the western boundary, both the pluton and its adjacent country rock experienced a ductile deformation with an N35E W55 foliation and N130E NW lineation (location (2)in Fig. 2). There, a mylonitic fabric develops in the granite (Fig. 3b). Quartz and feldspar grains are deformed into sigmoidal shapes that indicate a top-to-the-NW shear sense. This ductile shear zone is a normal fault indicating the rising up of the pluton with respect to its country rock.

The Qingyang-Jiuhua massif is surrounded by a metamorphic aureole of several hundred meters to $1 \mathrm{~km}$ in width (Fig. 2). Marble and andalusite hornfels are the dominant rock-types. The marble is formed by coarse grain calcite (locations (4), (6) and (8in Fig. 2), while the andalusite hornfels is composed of very fine grain quartz, feldspar, muscovite, phyllite and andalusite (locations (2.) (3.) (5)and (7)in Fig. 2). These contact metamorphic rocks are well foliated. The foliations are roughly parallel to the granite boundary (locations (2. (3.) (5.) (6) (7)and (8)in Fig. 2). In location (3) which is in the aureole zone near the west boundary of the studied massif, the foliation measured in marble and andalusite hornfels are N190E W70, and in location 5. the foliation in andalusite hornfels is N30E 90. At the outcrop scale, the dark and 
elongated andalusite aggregates are well oriented to form a mineral lineation (Fig. 3c). The lineation is seldom observed. When it occurs, it exhibits a down-dip attitude, for example the lineation in location (5) is vertical.

\subsection{Microgranitoid enclave orientation}

Microgranitoid enclaves are widespread in the Qingyang-Jiuhua massif. Most enclaves have been stretched and some enclaves were cracked and injected by magma indicating magma flowing during emplacement (Fig. 3d). The limited outcrop conditions allowed us to measure only the $2 \mathrm{D}$ fabrics of these microgranitoid enclaves. The enclave long axis orientation in each site indicates a dominant NW-SE to E-W preferred orientation more or less consistent with the magmatic fabrics illustrated in the 1:200000 geologic map of the studied massif (Figs. 2 and 4).

\subsection{Microscopic structures}

Field observations indicate that the main body of the massif appears as isotropic. The ductile deformation only locally occurs in the granite and its country rocks near the pluton boundary. In order to better constrain the deformation mechanics and shear sense of the boundary of the massif, structural observations were conducted at the microscope-scaled thin sections from both granite and country rock. Several oriented thin sections were prepared from hand samples and AMS cores (see below). The thin sections were cut perpendicular to the foliation and parallel to the lineation when recognized in hand sample, or magnetic foliation and lineation for AMS cores. Three 
types of microstructures have been recognized, namely granitic structure, weak ductile deformation, and intense ductile deformation.

Firstly, the magmatic structure is found in the main parts of both Qingyang and Jiuhua plutons. In thin sections parallel to the AMS lineation and perpendicular to the AMS foliation, post solidus deformation features are absent. The amphibole occurs as euhedral crystal habit (Figs. 3e). The plagioclase is characterized by igneous zoning, polysynthetic twins, euhedral to semi euhedral crystal habits (Figs. 3e, $3 \mathrm{f}$ and $3 \mathrm{~g}$ ). The K-feldspar contains flame microperthite and Carlsbad twins are well developed in many grains. Biotite exhibits a sharp extinction and no cleavage bend (Fig. 3e). Quartz has anhedral shape, which indicates that it crystallized from a melt (Figs. 3e and 3f). Many quartz grains have subgrain boundaries and both quartz and feldspars are characterized by a weak undulose extinction showing that the rock experienced a limited deformation at the end of the crystallization of the melts, and thus the magmatic texture is not altered (Paterson et al., 1989).

Secondly, a weak ductile deformation is found in the country rock on the southeastern and northeastern boundaries of the massif. Along these margins, the country rocks are represented by andalusite hornfels in which the andalusite forms dark needles of 1 or $2 \mathrm{~mm}$ in size of (Fig. 3c). In the northwestern boundary of the septum (location (5) in Fig. 2), the foliation in the hornfels is oriented at N60E NW75, which is parallel to the sedimentary bedding and the granite boundary. The andalusite lineation is nearly vertical. The observation of oriented thin section shows that in hornfels, andalusite aggregates exhibit a sigmoidal shape with tiny quartz tails 
(Fig. 3h). The shear sense shows that the NW side (pluton side) rises up and the SE side (country rock side) moves down.

On the northeastern boundary, the granitoid rocks are still weekly ductilely deformed. The plagioclase is magmatically zoned and euhedral. Many tiny grains due to dynamic crystallization develop around plagioclase clasts (Fig. 3i). K-feldspar has a flame microperthite texture and an euhedral shape. On the grain boundary, myrmekite texture replaces K-feldspar. The quartz is anhedral with sutured grain boundaries and subgrains boundary (Fig. 3i). These three minerals have a undulose extinction. Biotite is sometimes bended and undulose. Amphibole shows a sharp extinction and a euhedral habitus without deformation.

Thirdly, intense ductile deformation is only found on the northwestern boundary (location (2) in Fig. 2). In oriented thin sections, stretched quartz grains form polycrystalline ribbons. K-feldspars deformed into a sigmoidal shape are sigma-type porphyroclasts (Fig. 3j). Some feldspar grains are crushed and rotated as dominos or book shelf microstructure (Fig. 3k). The shear sense indicators show a top-to-the- NW motion that can be related to the pluton side rise with respect to the country rock.

\subsection{Regional fold geometry and pluton emplacement}

The Qingyang-Jiuhua massif intrudes into the Yangtze fold belt. In agreement with previous works, our study shows that, the fold geometry developed in the country rocks is abruptly interrupted by the granitic intrusion. The strike of fold axis is not defected by the plutons. Moreover, in the metamorphic aureole, folds that might be 
considered as the result of a shortening effect of the country rock during the emplacement of the pluton are absent.

\section{Rock magnetism}

\subsection{Sampling and measurement}

As illustrated by numerous case studies during past decades, AMS fabric pattern of a pluton may reflect the tectonic regime during its emplacement while the paleomagnetic records are easily to be influenced by the tectonic event after the crystallization of the pluton (Bouchez and Gleizes, 1995; Talbot et al., 2005a; Joly et al., 2007; Charles et al., 2011; Lin et al., 2013). These two methods are applied to investigate different scaled deformation and tectonic characteristics of the study area.

In order to obtain a general view of the AMS features of the Qingyang-Jiuhua massif, AMS sampling is performed with 93 sites covering this massif by gasoline drill (Table 1). These sites are ca. $2 \mathrm{~km}$ away with a relatively homogeneous spatial distribution within the pluton (Fig. 9). For each site, 5 to 6 cores of $2.5 \mathrm{~cm}$ in diameter with an interval of about 2 meters are drilled and oriented by both magnetic and, when possible, solar compasses. The cores are cut into standard AMS specimens with a length of $2.2 \mathrm{~cm}$ in the laboratory. As a result, 5 to 11 specimens were obtained for each site and a total of 652 specimens for the whole massif.

In order to constrain the relative movement of the Jiuhua pluton with other 4 subplutons of the Qingyang pluton during and after their crystallization (Fig. 2), 15 specimens from the Jiuhua pluton (J), 12 specimens from the west subpluton (W), 11 
specimens from the south subpluton (S), 10 specimens from the north subpluton $(\mathrm{N})$, 12 specimens from the southeast subpluton (SE) of the Qingyang pluton were taken for the paleomagnetic measurements.

In Laboratoire de Magnétisme des Roches d'Orléans, IRM experiments were carried out on different lithologies by IM30 pulse magnetizer and JR5 magnetometer. Coupled with a CS3 furnace, KLY3 was used to perform the thermal-susceptibility experiments on powders of different lithologies. The KLY3 kapabridge was used to perform the AMS and bulk susceptibility measurements. The results were processed by ANISOFT (offered by AGICO) to calculate the main magnetic anisotropic axes $\left(\mathrm{K}_{1}\right.$ for lineation and $K_{3}$ for the pole of foliation), the shape parameter (T) and the anisotropy degree $\left(\mathrm{P}_{\mathrm{J}}\right)$ using Jelinek statistics (Jelinek, 1981). To get the paleomagnetic record, both progressive AF and thermal demagnetizations were used to clean the magnetic remanence with about 15 steps. JR5 magnetometer was used to measure the magnetic remanence. Moreover, hysteresis curves were obtained by an electromagnetic inductometer on different lithologies in the Paleomagnetic laboratory of Institut de Physique du Globe de Paris.

\subsection{Magnetic mineralogy}

To better interpret the AMS and magnetic remanence measurements, it is essential to recognize their carriers because the magnetic record depends on the magnetic mineralogy, relative abundance and size (e.g. Tarling and Hrouda, 1993).

Figure 5 presents the distributions of bulk magnetic susceptibility of measured 
specimens. The granodiorite and monzogranite show a unimodal and large distribution with an average of $\mathrm{Km}$ higher than $15 \times 10^{-3} \mathrm{SI}$, while the acidic dykes reveal a narrow distribution centered at about $4 \times 10^{-3}$ SI. It is worth noting that most of the specimens show relatively high bulk susceptibilities in order of $10^{-3} \mathrm{SI}$ with few exceptions, such as Site CZ63 and CZ14 composed of acidic dykes (Table 1).

The thermal experiments show that a sharp drop of the magnetic susceptibility has been observed for all measured samples at ca. $580^{\circ} \mathrm{C}$ (Figs. 6a, 6b, 6c, 6d and 6e), indicating the dominance of magnetite in the magnetic mineral composition of collected samples. In detail, some samples show a slow decrease of magnetic susceptibility to zero until to at ca. $700^{\circ} \mathrm{C}$ (Figs. 6a, 6b, 6d and 6e), implying the existence of hematite.

The IRM acquisition diagram shows a rapid increase of the induced magnetization before $100 \mathrm{mT}$ (Figs. 6f, 6g, 6h, 6i and 6j) and all measured samples are saturated before $200 \mathrm{mT}$ (Figs. 6g, 6h, 6i and 6j), except for the acidic dyke (Fig. 6f), which is only saturated at $80 \%$ at this field. This observation indicates that the weak coercive minerals, such as magnetite, are dominant regardless of their differences in lithology.

The hysteresis loops present shaped sigmoidal shapes, indicating the existence of magnetite (Figs. 6k, 6l, 6m, 6n and 6o). According to these measurements, the magnetite sizes have been estimated, revealing the pseudo-single domain and multi-domain for the magnetite (Fig. 7; Dunlop, 2002)

In summary, the pseudo-single domain and multi-domain magnetites that have been documented can be considered as the main carriers for the magnetic susceptibility and 
remanence for investigated lithotologies of this study. This conclusion is consistent with microscopic observations shown in Figures $31,3 \mathrm{~m}$ and $3 \mathrm{n}$. Therefore, the magnetic fabrics may be directly correlated with magmatic or tectonic fabrics (e.g. Tarling and Hrouda, 1993).

\subsection{AMS results}

\subsubsection{Anisotropy degree and shape parameter}

The statistical results of AMS measurement of the Qingyang-Jiuhua massif are presented in Table 1. For each site, the coordinate data of a sampling location, the mean bulk susceptibility $(\mathrm{Km})$, the anisotropy degree $\left(\mathrm{P}_{\mathrm{J}}\right)$, the shape parameter $(\mathrm{T})$, the mean direction of declination and inclination of $\mathrm{K} 1$ and $\mathrm{K} 3$ axes as well as their corresponding confidence ellipse $\left(\alpha_{95}\right)$ are provided (Jelinek, 1981). In the $\mathrm{P}_{\mathrm{J}}-\mathrm{Km}$ diagram (Fig. 8a) most sites (90\%) show a $\mathrm{Km}$ value below $40 \times 10^{-3} \mathrm{SI}$ with a $\mathrm{P}_{\mathrm{J}}$ value below 1.2. Moreover, there seems to exist a trend of $\mathrm{P}_{\mathrm{J}}$ vs $\mathrm{Km}$ (the shadowed zone in Fig. 8a). Few sites (CZ16, CZ48, CZ63, CZ68, CZ72, CZ73, CZ75, CZ82, CZ92; location see Fig. 9) show high $\mathrm{P}_{\mathrm{J}}$ values (> 1.2) and are far away from the $\mathrm{P}_{\mathrm{J}} \mathrm{vs}$ $\mathrm{Km}$ trend. This may be due to their close spatial relationship with country rocks. Most sites show a positive value for their shape parameter $(\mathrm{T})$, revealing the foliation dominance for the magnetic fabrics. No obvious relationship between $T$ and $P_{J}$ parameters can be observed (Fig. 8b).

\subsubsection{AMS fabrics}


Figures $9 \mathrm{a}$ and $9 \mathrm{~b}$ present the mean directions of magnetic lineation $\left(\mathrm{K}_{1}\right)$ and pole of magnetic foliation $\left(\mathrm{K}_{3}\right)$ of each site from the Juhua pluton and the Qingyang pluton, respectively. It can be found that the magnetic fabrics are well defined for most sites, and the magnetic foliation of both the Jiuhua pluton (Fig. 9a) and the Qingyang pluton (Fig. 9b) are better constrained than the magnetic lineation for most individual sites. The magnetic lineations of both plutons are characterized by weakly inclined and largely scattered orientations (Figs. 9 and 10). Near the boundary between the massif and the country rocks, the magnetic lineation of most sites is more or less parallel to the strike of the boundary (Figs. 9 and 10). The foliation orientations are more complicated. Two main groups may be defined: flat and highly inclined foliations. The sites that present highly inclined magnetic foliations are principally localized near lithological boundaries (dyke-pluton, pluton-pluton, pluton-country rock). For instance, Sites CZ47 and CZ58 are localized on the boundary of two plutons (Fig. 9b), CZ16, CZ72 and CZ 92 are close to the country rocks (Fig. 9b), and CZ03 and CZ05 are dykes (Fig. 9a). The directions of these foliations are generally parallel to the boundaries (Fig. 9). The remained magnetic foliations observed from the central parts of plutons can be characterized by a flat pattern (Figs. 9, 10 and 11).

\subsection{Paleomagnetic results}

Among the 60 specimens selected for the paleomagnetic study, 55 have been successfully measured (Table 2; 14 from the Jiuhua pluton and 41 from the 4 subplutons of the Qingyang pluton; others were broken during the heating). Twenty of 
them have been progressively demagnetized by the AF technique and the remained 35 specimens are treated by thermal demagnetization with about 15 steps. Magnetic remanence directions were determined by a principal component analysis (Kirschvink, 1980). Inclinations and declinations obtained by progressive demagnetization were plotted on orthogonal vector diagrams (Zijderveld, 1967). Site-mean (the Jiuhua pluton and the subplutons of the Qingyang pluton) directions were computed with Fisher statistics (Fisher, 1953). Paleomagnetic software packages of J.P. Cogné (Cogné, 2003) and R. Enkin (unpublished) were used for the data analysis.

Most specimens show a single component after having removed the viscous magnetization at lower temperature $\left(100^{\circ} \mathrm{C}\right.$; Figs. $12 \mathrm{a}$ and $\left.12 \mathrm{~b}\right)$ or magnetic field (2mT; Fig. 12c). The magnetic remanence can be cleaned up at about $585^{\circ} \mathrm{C}$ or about $10 \mathrm{mT}$, reconfirming the magnetite as the main remanence carrier. The reversed magnetic direction has been also observed on several specimens (Fig. 12d). For the specimens showing a single direction, the component may be isolated between 150 and $585^{\circ} \mathrm{C}$ or 2 to $10 \mathrm{mT}$. Concerning the specimens presenting both normal and reversed directions, the normal component can be isolated from 150 to $470^{\circ} \mathrm{C}$ and the reversed one from 470 to $585^{\circ} \mathrm{C}$.

To compare the directions among the subplutons within the Qingyang pluton and those between the Qingyang and Jiuhua plutons, the mean magnetic directions have been calculated from high temperature/AF components for the Jiuhua pluton and each subpluton of the Qingyang pluton, showing a good consistence (Fig. 13a and Table 2). It is worth noting that both normal and reversed directions have been observed in the 
older Qingyang pluton, but only single normal one in the younger Jiuhua pluton (Table 2).

\section{Discussion}

To understand the tectonic context and the mechanism of the Qingyang-Jiuhua massif emplacement, the deformation in different scales has been investigated in this study by different methods: microscopic observation on thin section, AMS, field structural observation and paleomagnetism. In order to provide a clear vision on the results from both field observation and laboratory measurements, in this discussion, we will firstly summarize these observations and then interpret them in terms of deformation within the massif, the regional tectonic context and the mechanism of the massif emplacement.

\subsection{Summary of observations}

In the field, the observation on this massif of $750 \mathrm{~km}^{2}$ shows that igneous rocks have an isotropic fabric in most parts of the pluton. Along the contact zone between the pluton and country rocks locally developed, foliation and lineation are parallel to the contact, and downward plunging, respectively. However, in most places no visible deformation can be observed along the contact between the pluton and host rocks. Long axes of enclaves indicate a dominant NW-SE to E-W preferred orientation, more or less consistent with the magmatic fabrics illustrated in the 1:200000 geologic map of the studied massif (Fig. 2). In the country rocks, a regional ductile shear zone is absent. The ductile deformation only occurs in the aureole zone in which the foliation 
is consistent with the geometry of the contact, and the stretching lineation is vertical when it occurs. In the laboratory, microscopic observations indicate a predominant magmatic texture, while the post-solidus deformation texture only occurs on a few sites along the boundary between the massif and its country rocks. AMS measurements on 652 specimens of 93 sites present a weak anisotropy degree $\left(\mathrm{P}_{\mathrm{J}}\right)$, and positive values of shape parameter (T) for the majority of sites. Globally, at the scale of the entire massif, the magnetic fabric is characterized by horizontal and scattered lineation, when it is located on the boundary of the massif, it follows the boundary contour; a flat and vertical foliation in the central part and the border of plutons, respectively. The paleomagnetic investigation on 55 samples from the Qingyang-Jiuhua massif statistically reveals coherent paleomagnetic directions with both normal and reversed magnetic polarities in four subplutons of the older Qingyang pluton and only normal one in the younger Jiuhua one.

\subsection{Deformation within the massif}

Structural and textural observations, acquired both in the field and laboratory, provide the direct data to argue for the emplacement mechanism. The microscopic observations on thin sections indicate magmatic textures, while the outcrop-scaled macroscopic observations in the field indicate that the main body of the massif is isotropic. The microgranitoid enclaves may be considered as passive strain markers and their preferred orientation may reflect the magmatic process although it is not universally accepted (Paterson et al., 2004 and references therein). Throughout the 
magmatic process, due to the higher content of mafic minerals in enclave than its host granitic rocks which lead to the earlier crystallization of the former than latter, the viscosity contrast between these two kinds of rocks is low in the initial stage; high in the second stage in which the enclave is highly crystallized while the host granite is still lowly crystallized; and low again in the last stage in which the host granitic rocks is highly crystallized same as the enclave. So in these tree stage, the enclave may deformed due to the magma flow to form a stretched shape and preferred orientation in the first stage, act as rigid objects transported, rotated and cracked in the magma by convection in the second stage, and deformed together with host granitic rock again in the last stage, respectively (Caricchi et al., 2012). In this course, the shape fabric of the enclave becomes statistically oriented parallel to magmatic fabrics (e.g. Williams and Tobisch, 1994). In this study, numerous microgranitoid enclaves exhibit an angular shape and boudinage (Fig. 3d). Near the contact zone, the preferred orientation of these microgranitoid enclaves is parallel to both the magmatic foliation and the contact interface (Fig. 2). AMS samples were collected from both host granitoid rocks and enclaves within one site to compare their magnetic fabrics (Site CZ61; Fig. 14). The results show that the magnetic fabrics of host granites and enclaves are undistinguishable, and that their anisotropy degrees and shape parameters are also comparable. The susceptibility of enclaves higher than that of granitoids can be accounted by the high content of mafic minerals in the former rocks. The consistency of the shape fabric and AMS fabric between enclave and its host granitic rocks mainly reveal a magmatic course, thus in the studied massif the post-solidus 
deformation is rather weak.

Ductile deformation only occurs on the boundary of the massif and the nearby metamorphic aureole as well. On the both the NW and SE boundaries, the shear sense deduced from the ductilely deformed igneous and country rocks indicates that the massif side rises up with respect to the country rocks (Figs. 3b, 3c, $3 \mathrm{f}$ and $3 \mathrm{~g}$ ).

The significance of an AMS fabric may be multiple (e.g. Tarling and Hrouda, 1993; Borradaile and Henry, 1997). According to various parameters, such as susceptibility carrier, mineral size, anisotropy degree, shape parameter, the magnetic fabric may reflect either the mineral shape preferred orientation formed during the magmatic crystallization stage, or the mineral deformation fabric acquired during a later tectonic stage. In these two different cases, the interpretation of the AMS fabrics is not the same. For the former, the fabric can be due to either magma flow or regional tectonics which exerts an influence on the melt before its final consolidation (e.g. Joly et al., 2009), while for the latter, the fabric results from regional tectonic events, after final crystallization of the pluton, which cause the deformation of the pluton as well as its country rocks (e.g. Bouchez and Gleizes, 1995).

In this study, the AMS fabric may be ascribed to the primary magmatic fabrics for several following reasons (Tarling and Hrouda, 1993). Firstly, our microscopic observations on thin sections, which are cut perpendicularly to the AMS foliation and parallel to the AMS lineation, do not reveal any post-solidus deformation (Figs. 3e, 3f and $3 \mathrm{~g}$ ); Secondly, the $\mathrm{P}_{\mathrm{J}}$ values of most specimens are below 1.2, indicating that the anisotropy did not originate from a post-solidus deformation. For a few exceptional 
cases, $\mathrm{P}_{\mathrm{J}}$ values above 1.2 can be explained by a border effect since these sites are located close to the pluton boundary (Figs. 8a, 9a and 9b). Thirdly, except for those specimens in the contact zone, all other specimens show that $\mathrm{P}_{\mathrm{J}}$ values varies in function of Km. This fact shows that the AMS ellipsoid can be reasonably correlated to the magnetite concentration instead of a posterior deformation (Charles et al., 2009). Consequently, the AMS fabric of the Qingyang-Jiuhua massif is ascribed to the magmatic flow, and/or regional tectonics event during syn-emplacement and late magmatic crystallization.

The paleomagnetic investigation also shows that a negligible deformation occurred within the pluton after the crystallization. The paleomagnetic directions from the Jiuhua pluton and 4 subplutons of the Qingyang pluton are statistically undistinguishable (Fig. 13a), implying that the younger Jiuhua intrusion did not produce any significant rotation among these subplutons. One might suspect this consistency of both elder and younger magnetic directions due to the remagnetization by the younger pluton emplacement. As described in Section 4.4, both normal and reversed directions have been isolated from the elder Qingyang pluton, however, only normal magnetic directions from the younger Jiuhua one (Figs. 12a, 12b, 12c and 12d). Therefore, the remagnetization possibility can be ruled out.

In summary, the results obtained by different methods, and at different observation scales, converge to point the same conclusion: the Qingyang-Jiuhua massif did not experienced a significant deformation either during or after its emplacement. 


\subsection{Implications on regional tectonics}

In the vicinity of the Qingyang-Jiuhua massif, no continuous ductile shear zone has been documented. The ductile deformation has been only observed on the boundary of the massif. This suggests that the study area experienced a weak deformation including the during the emplacement time of the Qingyang-Jiuhua massif.

AMS is often considered as an efficient tool to study weak deformation such as that developed in plutons (e.g. Tarling and Hrouda, 1993; Bouchez and Gleizes, 1995). Nevertheless, the significance of granitic fabrics of plutons depends on the competition between magma dynamics and regional tectonic strain (Faure and Pons, 1991; Borradaile and Henry, 1997). If the crystallization is fast, the regional tectonics does not have the possibility to leave its imprint on the AMS fabric of igneous rocks (e.g. Callot et al., 2001). On the contrary, if the pluton crystallization time is long enough, the characteristics of this tectonic event may be revealed by the AMS fabric (e.g. Archanjo and Bouchez, 1997; Archanjo et al., 1999; Neves et al., 2003; Zak et al., 2005, 2008;). Thus, when the tectonic strain is very weak, the pluton AMS fabric pattern will be controlled by magma flow (e.g. de Oliveira et al., 2010).

A good example is provided by AMS studies from granites in the Variscan French Massif Central. The well-grouped NW-SE striking magnetic lineation records well the NW-SE late-orogenic extension developed at the end of the Variscan orogeny, also documented by structural analysis of regional ductile normal faults, and pluton 
metamorphic aureoles (Joly et al., 2009; Talbot et al., 2005b). However, in our study, the shallow inclination scattered orientation of the magnetic lineation (Figs. 10 and 11b) might be due to the granitic magma flow under a weak regional tectonic influence during the late stage of crystallization (e.g. de Oliveira et al., 2010).

Several authors have emphasized the importance of the tectonic activity in the lower Yangtze area during the Cretaceous period, with contrasting directions ( Lin et al., 2000; Faure et al., 2003; Mercier et al., 2007; Zhu et al., 2010a). An NE-SW extension, at ca. $145 \mathrm{Ma}$, is reported in the Hongzhen "metamorphic core complex" (Zhu et al., 2010a); an Early Cretaceous NW-SE stretching is recognized in the Lushan, Dabieshan, and along the Tanlu fault (Faure et al., 2003; Wu et al., 2007); a ca. $126 \mathrm{Ma}$ NE-SW stretching is recognized in the Lushan massif (Lin et al., 2000), and a sinistral transcurrent motion developed from ca. $127 \mathrm{Ma}$ to ca. $105 \mathrm{Ma}$ along the Tanlu fault (Mercier et al., 2007). In order to clarify this controversy, we try to find if there is a relative movement of the study area with respect to its surrounding zones. As all the paleomagnetic directions from the Qingyang subplutons and the Jiuhua pluton show a good consistency, we can calculate a paleomagnetic pole at $82.5^{\circ} \mathrm{N}$, $220.1^{\circ} \mathrm{E}, \mathrm{A}_{95}=5.7^{\circ}$ with $\mathrm{n}=5$ (Table 2; square in Fig. $13 \mathrm{~b}$ ). We take SCB as reference and its Cretaceous pole for the comparison (see Wu et al., 1998 for details of this average pole). The weak angular difference $\left(3.5^{\circ} \pm 7.3^{\circ}\right)$ between these two paleomagnetic poles indicates that no paleomagnetically detectable relative movement occurred between the study area and SCB after the massif crystallization. Though keeping the weak resolution of the paleomagnetism in mind, we can conclude the 
intensive deformation observed in some zones, such as in the Dabie and Lushan massifs, concerns just local and limited areas. Moreover, if any strike-slip movement took place in the region, it could not be very important.

\subsection{Hypothesis on the emplacement mechanism of the massif}

The emplacement mechanism of granitoid can be divided into forceful and permissive types according to the manners of room creation (Pitcher, 1979). This can be identified by the impact exerted on country rocks by the granitoid emplacement. In the former type, granitic magma occupy the room created by pushing away the country rock during the pluton emplacement. In this case, the previous structures of the country rock, such as folds and faults, are modified, and several pluton emplacement-related structures such as folds, foliation, and mineral lineation develop around the massif in response to the pressure created by the crystallizing magma. While in the latter type, the emplacement of pluton has more links to the regional tectonics context because the room is created by a regional deformation coeval with the magma intrusion.

Based on the above discussion, our structural observations and the AMS fabric pattern favor a permissive mechanism by vertical magmatic injection, as illustrated in Figure 15.

1) The main body of the Qingyang-Jiuhua massif is isotropic both at macroscopic and microscopic scales, e.g. quartz and feldspars show only an undulose extinction. This means that during the granite crystallization, the massif recorded a 
weak pressure effect that was unable to induce a significant structural effect on the country rocks, since there is neither modification of the previous fold geometry developed in the whole Yangtze fold belt (Fig. 2), nor creation of fold in the aureole. The magma emplacement just caused the local ductile shearing along the boundary surface, which could imply the ascent of the magma relatively to its country rocks (Figs. 2 and 15). This means that the space occupied by the massif was probably created by regional tectonics during the magma intrusion.

2) The fact that the emplacement of the younger Jiuhua pluton did not make any significant tilt of the Qingyang pluton, as shown by our paleomagnetic study (Fig. 13a) argues that the space was not created by pushing away the country rocks during the emplacement of the Jiuhua pluton.

3) The fabric distribution pattern supports a permissive emplacement mechanism of vertical magma injection.

Usually, when a vertically ascending magma stops near its final location, due to the blocking of the overlying country rocks and the pressure from the successive extruding magma beneath (arrows in Fig. 15), the foliation in the localities near the roof and side vertical surface of the pluton would be parallel to the boundary between the pluton and its country rocks. This generally leads to a flat foliation near the roof of the pluton and a boundary-concordant arrangement of the steep foliation near the pluton margins. When magma reaches the roof of the massif, in its central part, it will flow horizontally. This mechanism explains the flat lying foliation, and the low inclined scattered magnetic lineation in the central part of the massif. While near the 
boundaries between the pluton/massif and its country rocks, the magnetic lineation will be horizontal and parallel to the boundary. (Fig. 11)

Field observations show that the exposures of the Qingyang-Jiuhua massif are close to the pluton roof. There exists a NE-SW oriented narrow strip of sedimentary country rock zone in the southeastern part of the Qingyang pluton (location 5in Fig. 2). Considering its narrow shape, it could be interpreted as septum with the igneous rock joint together beneath.

The shape parameter $\mathrm{T}$ values of most specimens are above 0 , presenting a dominance of oblate shapes for AMS fabrics. Together with microscopic observations of the undulose extinction of quartz and feldspar by indicate magma crystallization under the pressure produced by subsequent magma injection.

The most obvious feature of AMS foliation is that the majority of the magnetic foliations is weakly inclined (Fig. 11a; e.g. CZ22, CZ68, CZ9, CZ35 and CZ29 in Fig. 15), and the highly inclined ones dominate along the massif boundaries where they are oriented parallel to the boundaries (Fig. 11a; e.g. CZ58, CZ 33 and CZ72 in Fig. 15). Enclave preferred orientation observed in this study, and the magmatic fabrics described by previous investigations shown in the 1:200000 geologic map of the Qingyang-Jiuhua massif (Fig. 2) also show a tendency to this accordance of the granite foliation with the massif boundary. This suggests an existing room when magma intrudes into.

According to the observations of deformation in different scales and the above discussion, it seems that the study region experienced a relatively weak deformation 
during the Cretaceous, even if the regional tectonics seems to play the most important role in the massif emplacement with respect to the internal magma dynamics.

\section{Conclusions}

For the purpose of understanding the tectonic context and mechanism of the emplacement of the Qingyang-Jiuhua massif, a multidisciplinary study has been carried out to investigate different scaled deformations from magnetic mineral fabric and petrographic texture to granitoid pluton and regional scale tectonics. The principal results are the following.

1. The composite Qingyang-Jiuhua massif mainly recorded an isotropic magmatic fabric, although a weak ductile deformation has been observed in the rocks of the border zone between the massif and country rocks. Both field observation and AMS measurement reveal flat or highly inclined foliations in the central or border zones of the massif, respectively.

2. The good consistency of the fold orientation in the study area around the massif with respect to the regional fold belt indicates that the granite emplacement did not modify the original tectonic framework.

3. The newly obtained paleomagnetic results confirm this observation, since no significant relative movements have been paleomagnetically detected either within the different parts of the massif or with the surrounding areas.

4. A possible emplacement mechanism involving a vertical and permissive intrusion of the Qingyang-Jiuhua massif accommodated by a relatively weak regional 
deformation during Late Mesozoic can be put forward.

This emplacement mechanism, based on surface structural observations and AMS analyses, remains a working hypothesis that needs further assessment. In order to improve this interpretation and the understanding of the contemporaneous regional tectonic framework, more information, such as the depth of emplacement and the 3D geometric characteristics of the massif, is needed. These additional data will allow us to better understand the textural features of AMS results and magma feeding processes.

\section{Acknowledgements}

The first author benefited a scholarship from the Sino-European Joint Doctoral Promotion Program (DPP) of the Chinese Academy of Sciences for his Ph.D. stay at ISTO (Orléans University-CNRS, France). This study was funded by the Chinese National 973 Project (2009CB825008), National Natural Science Foundation of China (41225009), the Innovative Project of the Chinese Academy of Sciences (Grant No. KZCX1-YW-15-1), the Major National Science and Technology Project (No. 2011ZX05008-001), and the Ministry of Land and Resources grant (201211024-04). Dr. Bernard Henry and Dr. Sanzhong Li are thanked by there constructive comments to improve the manuscript.

\section{References}

AHBGMR, 1987. Regional geology of Anhui Province. geological plublishing house, 
Beijing, China.

Archanjo, C.J., Bouchez, J.L., 1997. Magnetic fabrics and microstructures of the post-collisional aegirine-augite syenite Triunfo pluton, northeast Brazil. Journal of Structural Geology 19, 849-860.

Archanjo, C.J., da Silva, E.R., Caby, R., 1999. Magnetic fabric and pluton emplacement in a transpressive shear zone system: the Itaporanga porphyritic granitic pluton (northeast Brazil). Tectonophysics 312, 331-345.

Borradaile, G.J., Henry, B., 1997. Tectonic applications of magnetic susceptibility and its anisotropy. Earth-Science Reviews 42, 49-93.

Bouchez, J.L. and Gleizes, G., 1995. 2-stage deformation of the Mont-Louis-Andorra granite pluton (Variscan Pyrenees) inferred from magnetic-susceptibility anisotropy. Journal of the Geological Society 152, 669-679.

Callot, J.P., Geoffroy, L., Aubourg, C., Pozzi, J.P., Mege, D., 2001. Magma flow directions of shallow dykes from the East Greenland volcanic margin inferred from magnetic fabric studies. Tectonophysics 335, 313-329.

Caricchi, L., Annen, C., Rust, A., Blundy, J., 2012. Insights into the mechanisms and timescales of pluton assembly from deformation patterns of mafic enclaves. Journal of Geophysical Research-Solid Earth 117.

Charles, N., Chen, Y., Augier, R., Gumiaux, C., Lin, W., Faure, M., Monie, P., Choulet, F., Wu, F.Y., Zhu, R.X., Wang, Q.C., 2011. Palaeomagnetic constraints from granodioritic plutons (Jiaodong Peninsula): New insights on Late Mesozoic continental extension in Eastern Asia. Physics of the Earth and Planetary 
Interiors 187, 276-291.

Charles, N., Faure, M., Chen, Y., 2009. The Montagne Noire migmatitic dome emplacement (French Massif Central): new insights from petrofabric and AMS studies. Journal of Structural Geology 31, 1423-1440.

Chen, J.F., Yu, G., Yang, G., Yang, S.H., 2005. A Geochronological framework of Late Mesozoic magmatism and metallogenesis in the Lower Yangtze valley, Anhui Province. Anhui Geology 15, 161-169.

Chen, J.F., Zhou, T.X., Li, X.M., Foland, K.A., Huang, C.Y., Lu, W., 1993. Sr and Nd isotopic constraints on source regions of the intermediate and acid intrusions from southern Anhui Province. Geochimica 1993, 261-268.

Cogné, J.P., 2003. PaleoMac: a Macintosh ${ }^{\mathrm{TM}}$ application for treating paleomagnetic data and making plate reconstructions. Geochemistry Geophysics Geosystems 4, 1007-1014.

Cong, B.L., Wang, Q.C., 1999. The New advantage in ultrahigh pressure metamorphic region in Dabie-Sulu Mountains. Chinese Science Bulletin 44, 1127-1141.

de Oliveira, D.C., Neves, S.P., Trindade, R.I.F., Dall'Agnol, R., Mariano, G., Correia, P.B., 2010. Magnetic anisotropy of the Redencao granite, eastern Amazonian craton (Brazil): Implications for the emplacement of A-type plutons. Tectonophysics 493, 27-41.

Dunlop, D.J., 2002. Theory and application of the Day plot (M-rs/M-s versus $\mathrm{H}-\mathrm{cr} / \mathrm{H}-\mathrm{c})$ 1. Theoretical curves and tests using titanomagnetite data. Journal of Geophysical Research-Solid Earth 107. 
Faure, M., Lin, W., Shu, L.S., Sun, Y., Scharer, U., 1999. Tectonics of the Dabieshan (eastern China) and possible exhumation mechanism of ultra high-pressure rocks. Terra Nova 11, 251-258.

Faure, M., Lin, W., Monie, P., Meffre, S., 2008. Palaeozoic collision between the North and South China blocks, Triassic intracontinental tectonics, and the problem of the ultrahigh-pressure metamorphism. Comptes Rendus Geoscience $340,139-150$.

Faure, M., Lin, W., Scharer, U., Shu, L.S., Sun, Y., Arnaud, N., 2003. Continental subduction and exhumation of UHP rocks. Structural and geochronological insights from the Dabieshan (East China). Lithos 70, 213-241.

Faure, M., Pons, J., 1991. Crustal thinning recorded by the shape of the Namurian-Westphalian leucogranite in the variscan belt of the northwest massif-central, France. Geology 19, 730-733.

Faure, M., Sun, Y., Shu, L., Monie, P., Charvet, J., 1996. Extensional tectonics within a subduction-type orogen. The case study of the Wugongshan dome (Jiangxi Province, southeastern China). Tectonophysics 263, 77-106.

Fisher, R., 1953. Dispersion on a sphere. Proceedings of the Royal Society of London Series a-Mathematical and Physical Sciences 217, 295-305.

Gilder, S.A., Gill, J., Coe, R.S., Zhao, X.X., Liu, Z.W., Wang, G.X., Yuan, K.R., Liu, W.L., Kuang, G.D., Wu, H.R., 1996. Isotopic and paleomagnetic constraints on the Mesozoic tectonic evolution of south China. Journal of Geophysical Research-Solid Earth 101, 16137-16154. 
Gilder, S.A., Keller, G.R., Luo, M., Goodell, P.C., 1991. Timing and spatial distribution of rifting in China. Tectonophysics 197, 225-243.

Goodell, P.C., Gilder, S., Fang, X., 1991. A preliminary description of the Gan-Hang failed rift, southeastern China. Tectonophysics 197, 245-255.

Hacker, B.R., Ratschbacher, L., Webb, L., Ireland, T., Walker, D., Shuwen, D., 1998. $\mathrm{U} / \mathrm{Pb}$ zircon ages constrain the architecture of the ultrahigh-pressure Qinling-Dabie Orogen, China. Earth and Planetary Science Letters 161, 215-230.

Jelinek, V., 1981. Characterization of the magnetic fabric of rocks. Tectonophysics 79, T63-T67.

Joly, A., Chen, Y., Faure, M., Martelet, G., 2007. A multidisciplinary study of a syntectonic pluton close to a major lithospheric-scale fault - Relationships between the Montmarault granitic massif and the Sillon Houiller Fault in the Variscan French Massif Central: 1. Geochronology, mineral fabrics, and tectonic implications. Journal of Geophysical Research-Solid Earth 112.

Joly, A., Faure, M., Martelet, G., Chen, Y., 2009. Gravity inversion, AMS and geochronological investigations of syntectonic granitic plutons in the southern part of the Variscan French Massif Central. Journal of Structural Geology 31, 421-443.

Kirschvink, J.L., 1980. The least squares line and the analysis of palaeomagnetic data. Geophysical Journal of the Royal Astronomical Society 62, 699-718.

Li, J.W., Zhou, M.F., Li, X.F., Fu, Z.R., Li, Z.J., 2001. The Hunan-Jiangxi strike-slip 
fault system in southern China: southern termination of the Tan-Lu fault. Journal of Geodynamics 32, 333-354.

Li, X.H., Li, W.X., Wang, X.C., Li, Q.L., Liu, Y., Tang, G.Q., Gao, Y.Y., Wu, F.Y., 2010a. SIMS U-Pb zircon geochronology of porphyry $\mathrm{Cu}-\mathrm{Au}-(\mathrm{Mo})$ deposits in the Yangtze River Metallogenic Belt, eastern China: Magmatic response to early Cretaceous lithospheric extension. Lithos 119, 427-438.

Li, S., Zhao, G., Zhang, G., Liu, X., Dong, S., Wang, Y., Liu, X., Suo, Y., Dai, L., Jin, C., 2010b. Not all folds and thrusts in the Yangtze foreland thrust belt are related to the Dabie Orogen: Insights from Mesozoic deformation south of the Yangtze River. Geological Journal 45, 650-663.

Li, Z.X., Li, X.H., 2007. Formation of the 1300-km-wide intracontinental orogen and postorogenic magmatic province in Mesozoic South China: A flat-slab subduction model. Geology 35, 179-182.

Lin, W., Charles, N., Chen, Y., Chen, K., Faure, M., Wu, L., Wang, F., Li, Q., Wang, J., Wang, Q., 2013. Late Mesozoic compressional to extensional tectonics in the Yiwulüshan massif, NE China and their bearing on the Yinshan-Yanshan orogenic belt Part II: Anisotropy of magnetic susceptibility and gravity modeling. Gondwana Research 2013, 78-94.

Lin, W., Faure, M., Monie, P., Scharer, U., Zhang, L.S., Sun, Y., 2000. Tectonics of SE China: New insights from the Lushan massif (Jiangxi Province). Tectonics 19, $852-871$.

Lin, W., Enami, M., Faure, M., Scharer, U., Arnaud, N., 2007. Survival of eclogite 
xenolith in a Cretaceous granite intruding the Central Dabieshan migmatite gneiss dome (Eastern China) and its tectonic implications. International Journal of Earth Sciences 96, 707-724.

Ling, M.X., Wang, F.Y., Ding, X., Hu, Y.H., Zhou, J.B., Zartman, R.E., Yang, X.Y., Sun, W.D., 2009. Cretaceous Ridge Subduction along the Lower Yangtze River Belt, Eastern China. Economic Geology 104, 303-321.

Liu, Q., Yu, J.H., Wang, Q., Su, B., Zhou, M.F., Xu, H., Cui, X., 2012. Ages and geochemistry of granites in the Pingtan-Dongshan Metamorphic Belt, Coastal South China: New constraints on Late Mesozoic magmatic evolution. Lithos 150, 268-286.

Mao, J., Xie, G., Duan, C., Pirajno, F., Ishiyama, D., Chen, Y., 2011. A tectono-genetic model for porphyry-skarn-stratabound $\mathrm{Cu}-\mathrm{Au}-\mathrm{Mo}-\mathrm{Fe}$ and magnetite-apatite deposits along the Middle-Lower Yangtze River Valley, Eastern China. Ore Geology Reviews 43, 294-314.

Mattauer, M., Matte, P., Malavieille, J., Tapponnier, P., Maluski, H., Xu, Z.Q., Lu, Y.L., Tang, Y.Q., 1985. Tectonics of the Qinling belt - buildup and evolution of eastern Asia. Nature 317, 496-500.

Mercier, J.L., Hou, M.J., Vergely, P., Wang, Y.M., 2007. Structural and stratigraphical constraints on the kinematics history of the southern Tan-Lu fault zone during the mesozoic Anhui Province, China. Tectonophysics 439, 33-66.

Neves, S.P., Araujo, A.M.B., Correira, P.B., Mariano, G., 2003. Magnetic fabrics in the Cabanas Granite (NE Brazil): interplay between emplacement and regional 
fabrics in a dextral transpressive regime. Journal of Structural Geology 25, 441-453.

Paterson, S.R., Vernon, R.H., Tobisch, O.T., 1989. A review of criteria for the indentification of magmatic and tectonic foliations in granitoids. Journal of Structural Geology 11, 349-363.

Paterson, S.R., Pignotta, G.S., Vernon, R.H., 2004. The significance of microgranitoid enclave shapes and orientations. Journal of Structural Geology 26, 1465-1481.

Pitcher, W.S., 1979. The nature, ascent and emplacement of granitic magmas. Journal of the Geological Society 136, 627-662.

Schmid, J.C., Ratschbacher, L., Hacker, B.R., Gaitzsch, I., Dong, S.W., 1999. How did the foreland react? Yangtze foreland fold-and-thrust belt deformation related to exhumation of the Dabie Shan ultrahigh-pressure continental crust (eastern China). Terra Nova 11, 266-272.

Shu, L.S., Faure, M., Jiang, S.Y., Yang, Q., Wang, Y.J., 2006. SHRIMP zircon U-Pb age, litho- and biostratigraphic analyses of the Huaiyu Domain in South China Evidence for a Neoproterozoic orogen, not Late Paleozoic-Early Mesozoic collision. Episodes 29, 244-252.

Shu, L.S., Zhou, X.M., Deng, P., Wang, B., Jiang, S.Y., Yu, J.H., Zhao, X.X., 2009. Mesozoic tectonic evolution of the Southeast China Block: New insights from basin analysis. Journal of Asian Earth Sciences 34, 376-391.

Shu, L.S., Zhou, X.M., Deng, P., Zhu, W.B., 2007. Mesozoic-Cenozoic Basin features and evolution of Southeast China. Acta Geologica Sinica-English Edition 81, 
573-586.

Sun, W.D., Ding, X., Hu, Y.H., Li, X.H., 2007. The golden transformation of the Cretaceous plate subduction in the west Pacific. Earth and Planetary Science Letters 262, 533-542.

Talbot, J.Y., Faure, M., Chen, Y., Martelet, G., 2005a. Pull-apart emplacement of the Margeride granitic complex (French Massif Central). Implications for the late evolution of the Variscan orogen. Journal of Structural Geology 27, 1610-1629.

Talbot, J.Y., Chen, Y., Faure, M., 2005b. A magnetic fabric study of the Aigoual-Saint Guiral-Liron granite pluton (French Massif Central) and relationships with its associated dikes. Journal of Geophysical Research-Solid Earth 110.

Tarling, D.H., Hrouda, F., 1993. The magnetic anisotropy of rocks. Chapman \& Hall, London.

Wang, Z.H., Lu, H.F., 2000. Ductile deformation and Ar-40/Ar-39 dating of the Changle-Nanao ductile shear zone, southeastern China. Journal of Structural Geology 22, 561-570.

Williams, Q., Tobisch, O.T., 1994. Microgranitic enclave shapes and magmatic strain histories: constraints from drop deformation theory. Journal of Geophysical Research 99, 24,359-24,368.

Wu, F.Y., Ji, W.Q., Sun, D.H., Yang, Y.H., Li, X.H., 2012. Zircon U-Pb geochronology and Hf isotopic compositions of the Mesozoic granites in southern Anhui Province, China. Lithos 150, 6-25.

Wu, H.N., Zhu, R.X., Bai, L.X., Guo, B., Lv, J.J., 1998. Revised apparent polar 
wander path of the Yangtze Block and its tectonic implications. Science in China (Series D) 41, 78-90.

Wu, Y.B., Tang, J., Zhang, S.B., Zhao, Z.F., 2007. SHRIMP zircon U-Pb dating for two episodes of migmatization in the Dabie orogen. Chinese Science Bulletin 52, $1836-1842$.

Xu, J.W., Zhu, G., Tong, W.X., Cui, K.R., Liu, Q., 1987. Formation and evolution of the Tancheng-Lujiang wrench fault system - a major shear system to the northwest of the Pacific Ocean. Tectonophysics 134, 273-310.

Xu, X.S., Suzuki, K., Liu, L., Wang, D.Z., 2010. Petrogenesis and tectonic implications of Late Mesozoic granites in the NE Yangtze Block, China: further insights from the Jiuhuashan-Qingyang complex. Geological Magazine 147, 219-232.

Yang, Q.G., Qiang, Cheng, W., Bo, Zhu, Q., Guang, Li, X., 2011. A discussion on two times southward thrusting of Xiangfan-Guangji Fault in South Dabie Orogen, Central China. Geological review 57, 480-494.

Yu, J.H., Zhou, X.M., Zhao, L., Jiang, S.Y., Wang, L.J., Ling, H.F., 2005. Mantle-crust interaction generating the Wuping granites: evidenced from $\mathrm{Sr}-\mathrm{Nd}-\mathrm{Hf}-\mathrm{U}-\mathrm{Pb}$ isotopes. Acta Petrologica Sinica 21, 651-664.

Yu, X.Q., Jiang, L.L., Xue, W., Qiu, R.L., Du, J.G., Dai, S.Q., 2007. Identification and basic characteristics of the Anhui-Zhejiang-Jiangxi fault zone. Earth Science Frontiers 14, 102-113.

Zak, J., Schulmann, K., Hrouda, F., 2005. Multiple magmatic fabrics in the Sazava 
pluton (Bohemian Massif, Czech Republic): a result of superposition of wrench-dominated regional transpression on final emplacement. Journal of Structural Geology 27, 805-822.

Zak, J., Verner, K., Tycova, P., 2008. Multiple magmatic fabrics in plutons: an overlooked tool for exploring interactions between magmatic processes and regional deformation? Geological Magazine 145, 537-551.

Zhang, Q., Wang, Y.1., Jin, W.J., Li, C.D., 2008. Eastern China Plateau during the Late Mesozoic: evidence, problems and implication. Geologcal Bulletin of China 27, 1404-1430.

Zhao, J.H., Hu, R.Z., Liu, S., 2004. Geochemistry, petrogenesis, and tectonic significance of Mesozoic mafic dikes, Fujian Province, Southeastern China. International Geology Review 46, 542-557.

Zhou, X.M., Li, W.X., 2000. Origin of Late Mesozoic igneous rocks in Southeastern China: implications for lithosphere subduction and underplating of mafic magmas. Tectonophysics 326, 269-287.

Zhou, X.M., Sun, T., Shen, W.Z., Shu, L.S., Niu, Y.L., 2006. Petrogenesis of Mesozoic granitoids and volcanic rocks in South China: A response to tectonic evolution. Episodes 29, 26-33.

Zhu, G., Xie, C.L., Chen, W., Xiang, B.W., Hu, Z.Q., 2010a. Evolution of the Hongzhen metamorphic core complex: Evidence for Early Cretaceous extension in the eastern Yangtze craton, eastern China. Geological Society of America Bulletin 122, 506-516. 
Zhu, G., Niu, M.L., Xie, C.L., Wang, Y.S., 2010b. Sinistral to Normal Faulting along the Tan-Lu Fault Zone: Evidence for Geodynamic Switching of the East China Continental Margin. Journal of Geology 118, 277-293.

Zijderveld, J.D.A., 1967. AC demagnetisation of rocks: analysis of results. Elsevier. 


\section{Figure and Table captions}

Figure 1. Regional geological map. DBM: the Dabie massif, LYTZFB: the Lower Yangtze fold belt, JNOB: the Jiangnan orogenic belt, TLF: the Tanlu fault, HZM: the Hongzhen massif.

Figure 2. Simplified geological map of the Qingyang-Jiuhua massif area. Q:

Quaternary, N: Tertiary, K: Cretaceous, T: Triassic, S: Silurian, O: Ordovician, $\in$ :

Cambrian, Z: Sinian, GD: Granodiorite of the Qingyang pluton, MG, Mongzogranite of the Jiuhua pluton, AD: Acidic dyke, J, N, W, S and SE represent for the Jiuhua pluton, the northern, western, southern and southeastern subplutons of the Qingyang pluton, respectively.

Figure 3. Macro- and micro- structures of the Qingyang-Jiuhua massif (a) Isotropic granodiorite of the Qingyang pluton. (b) Top-to-the NW ductile shearing on the NW boundary of the Qingyang granodioritic pluton (Location (2) in Fig. 2). (c) Andalusite porphyroblasts aligned in the aureole hornfels of the massif (Location (6) in Fig. 2). (d) Crack filled by granite in the microgranitoids enclave in Jiuhua pluton. (e) The sharp extinction of Quartz, polysynthetic twins of Plagioclase, Biotite without bend in granodiorite show a magmatic texture. (f). The sharp extinction of Quartz in monzogranite shows magmatic texture. $(\mathrm{g})$. Microscopic photo of acidic dyke show magmatic texture. (h) Sigmoidal andalusite porphyroblasts developed in the south 
eastern boundary of the Qingyang pluton showing a downard motion of the SE part (Location (5) in Fig. 2). (i) Weak post-solidus ductile deformation in the granite on the NE boundary (Location (1) in Fig. 2). (j) Sigmoidal shape of feldspar on the NW boundary (Location (2) in Fig. 2). (k) Domino structure of feldspar on the NW boundary of the Qingyang-Jiuhua Massif (Location (2) in Fig. 2). (1). Magnetite in granodiorite. (m). Magnetite in monzogranite. (1). Magnetite in acidic dyke.

Figure 4. Preferred orientation of microgranitoid enclaves (Sample locations shown in Figure 2).

Figure 5. Distribution of bulk magnetic susceptibility of the Qingyang-Jiuhua massif.

Figure 6. Thermal-Susceptibility, Isothermal Remanent Magnetization (IRM), Hysteresis Loop diagram of the Qingyang-Jiuhua massif.

Figure 7. Jrs/Js versus Hcr/Hc diagram from measured samples of the Qingyang-Jiuhua massif to define the magnetite size. Jrs: remanence, Js: saturation remanence, Hcr: coercivity of remanence, Hc: coercivity, SD: single domain, PSD: pseu-single domain, MD: multi-domain, respectively.

Figure 8. AMS scalar parameters of each site and main lithologies. (a) T (shape parameter) vs. $\mathrm{P}_{\mathrm{J}}$ (corrected anisotropy degree), (b) $\mathrm{P}_{\mathrm{J}}$ vs. Km (mean bulk magnetic 
susceptibility in $10^{-3} \mathrm{SI}$ ). The calculations of $\mathrm{T}$ and $\mathrm{P}_{\mathrm{J}}$ can be found in Jelinek (1981).

Figure $9 \mathrm{a}$ and $\mathrm{b}$ present the equal area lower hemisphere projection of each site from the dykes and the monzogranite of the Jiuhua pluton as well as the granodiorite of the Qingyang pluton respectively. Squares and circles stand for K1 (magnetic lineation) and K3 (pole of magnetic foliation), respectively. Small grey and larger black squares or circles represent individual specimen and site-mean direction, respectively with their confidence ellipses at $95 \%$ level.

Figure 10. Total fabrics projection (equal area lower hemisphere) of the Qingyang-Jiuhua massif. In this diagram, each solid square and circle represent one site. Data of 18 acidic dykes and 1 mafic dyke are not included in the statistics.

Figure 11 Magnetic foliation (a) and lineation (b) maps of the granitic rocks in the Qingyang-Jiuhua massif. Q: Quaternary, N: Tertiary, K: Cretaceous, T: Triassic, $\mathrm{Pz}_{2}$ : upper Paleozoic, S: Silurian, O: Ordovician, $\in$ : Cambrian, Z: Sinian.

Figure 12. Zijderveld diagrams (1967) of the thermal and AF demagnetization for the representative samples of the Jiuhua pluton (CZ81-29A) and the Qingyang pluton (others). Solid and open circle stand for horizontal and vertical plan, respectively.

Figure 13. Paleomagnetic results of the Qingyang-Jiuhua massif. (a) site-mean 
directions of the Jiuhua and blocks of the Qingyang pluton; (b) Paleomagnetic poles for the Qingyang-Jiuhua massif ( $\mathbf{\square})$ and South China Block ( $\boldsymbol{\Delta})$ with sampling locality ( $\star$ ).

Figure 14. Comparison of AMS fabrics of the microgranitoid enclave with the host monzogranite.

Figure 15. Emplacement model of the Qingyang-Jiuhua massif along AA' line (Fig. 2).

S: Silurian, O: Ordovician, $\in$ : Cambrian, $\mathrm{CZ}$ refers to the site number shown in Figs. $9 \mathrm{a}$ and $9 \mathrm{~b}$.

Table 1. The AMS results of granotoids from the Jiuhua-Qingyang massif.

Lat: latitude, long: Longitude, lith: lithology, km: mean magnetic susceptibility, $\mathrm{P}_{\mathrm{J}}$ and T: anisotropy degree and shape parameter, respectively, K1 and K3: magnetic lineation and pole of magnetic foliation, respectively, Inc: inclination, Dec: declination, $\quad a_{95} \max$ and $\quad{ }_{95} \min$ : long and short axis of ellipsoid uncertainty, respectively, GD: granoodiorite, $\mathrm{MG}$ : monzogranite, $\mathrm{DIO}$ : diorite, $\mathrm{AD}$ : acidic dyke, symbols of *, and \#: microgranitic, quartzose and pegmatitic dyke, respectively.

Table 2. Paleomagnetic results of high temperature magnetic components from the Qingyang-Jiuhua massif. 
$\mathrm{N}$ : specimen number, D: declination, I: inclination, k: precision parameter, $\mathrm{a}_{95}$ and A95: statistic confidence of paleomagnetic direction and paleomagnetic pole at $95 \%$ level, respectively, $\lambda, \phi, \mathrm{dp}$ and $\mathrm{dm}$ : latitude and longitude of paleomagnetic pole and its half radius of confidence in latitude and longitude, respectively, J: the Jiuhua pluton, W, S, N, SE: west, south, north, southeast subpluton of the Qingyang pluton. 


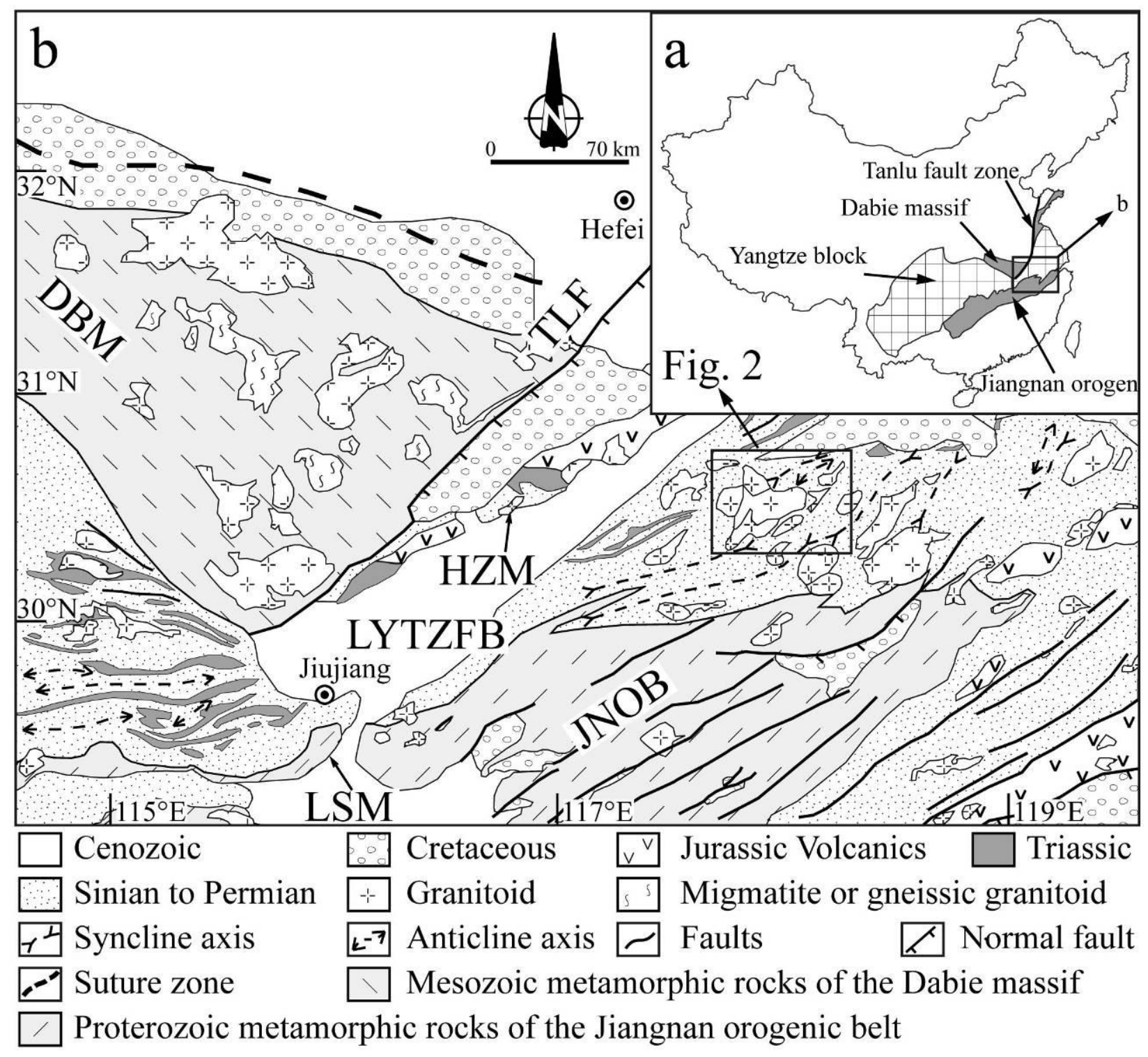

Figure 1. Regional geological map. DBM: the Dabie massif, LYTZFB: the Lower Yangtze fold belt, JNOB: the Jiangnan orogenic belt, TLF: the Tanlu fault, HZM: the Hongzhen massif. 


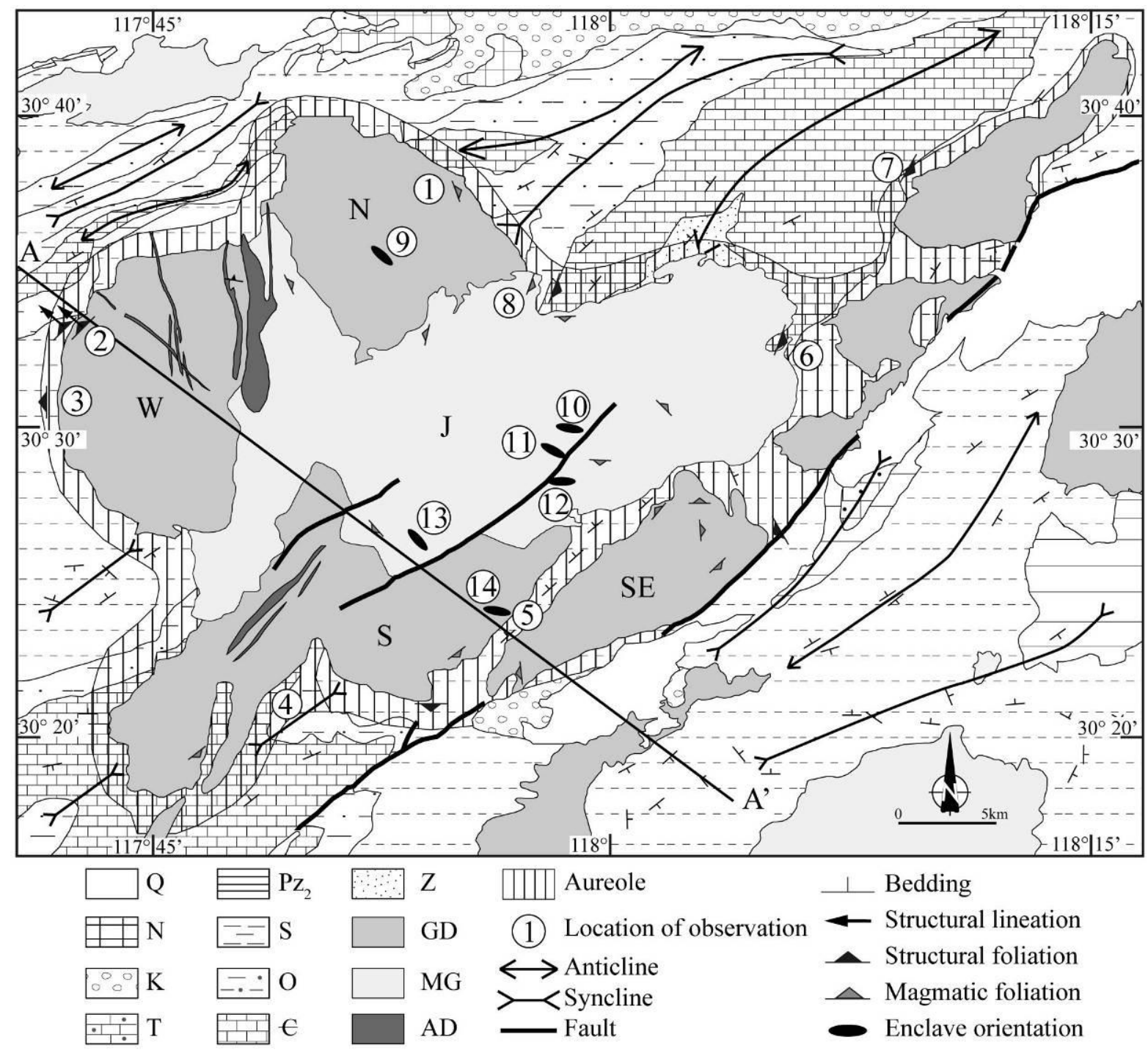

Figure 2. Simplified geological map of the Qingyang-Jiuhua massif area. Q: Quaternary, N:

Tertiary, K: Cretaceous, T: Triassic, S: Silurian, O: Ordovician, $\in$ : Cambrian, Z: Sinian, GD:

Granodiorite of the Qingyang pluton, MG, Mongzogranite of the Jiuhua pluton, AD: Acidic dyke, J,

N, W, S and SE represent for the Jiuhua pluton, the northern, western, southern and southeastern subplutons of the Qingyang pluton, respectively. 

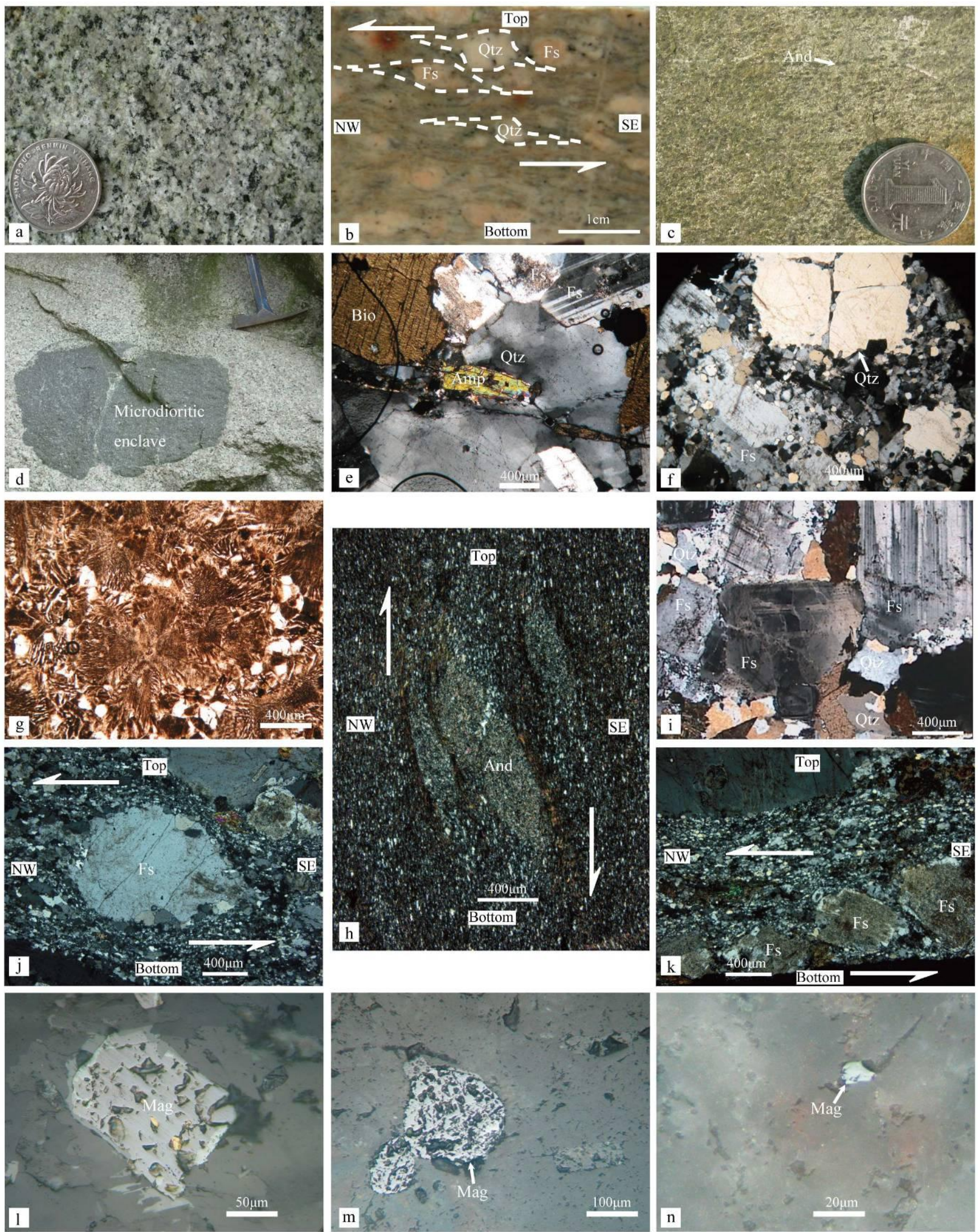

Figure 3. Macro- and micro- structures of the Qingyang-Jiuhua massif

(a) Isotropic granodiorite of the Qingyang pluton. (b) Top-to-the NW ductile shearing on the NW boundary of the Qingyang granodioritic pluton (Location (2) in Fig. 2). (c) Andalusite 
porphyroblasts aligned in the aureole hornfels of the massif (Location (6) in Fig. 2). (d) Crack filled by granite in the microgranitoids enclave in Jiuhua pluton. (e) The sharp extinction of Quartz, polysynthetic twins of Plagioclase, Biotite without bend in granodiorite show a magmatic texture. (f). The sharp extinction of Quartz in monzogranite shows magmatic texture. (g). Microscopic photo of acidic dyke show magmatic texture. (h) Sigmoidal andalusite porphyroblasts developed in the south eastern boundary of the Qingyang pluton showing a downard motion of the SE part (Location (5) in Fig. 2). (i) Weak post-solidus ductile deformation in the granite on the NE boundary (Location (1) in Fig. 2). (j) Sigmoidal shape of feldspar on the NW boundary (Location (2) in Fig. 2). (k) Domino structure of feldspar on the NW boundary of the Qingyang-Jiuhua Massif (Location (2) in Fig. 2). (1). Magnetite in granodiorite. (m). Magnetite in monzogranite. (1). Magnetite in acidic dyke. 


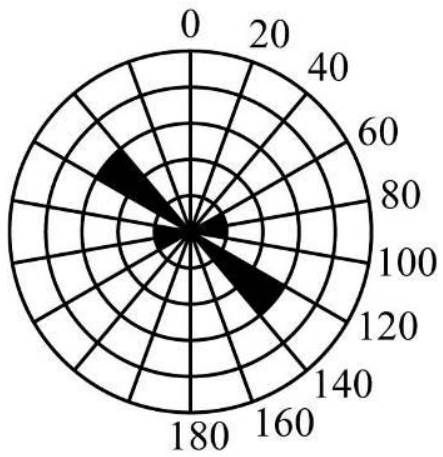

Location (9) N=5

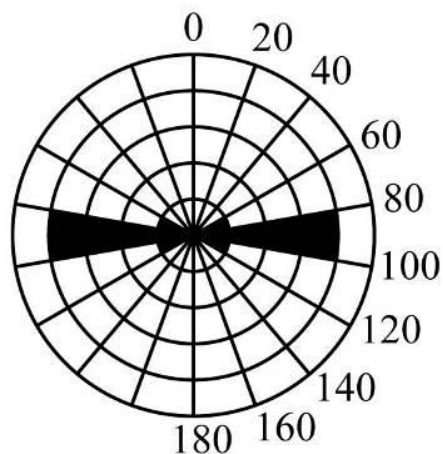

Location (12) $\mathrm{N}=6$

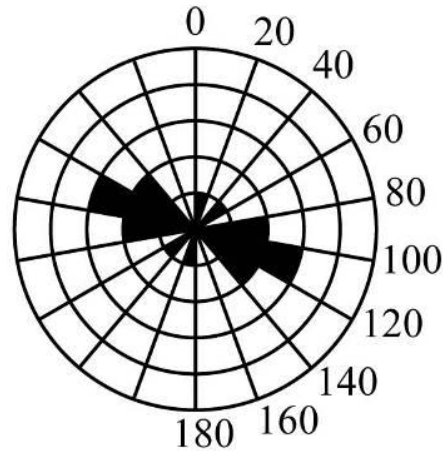

Location (10) $\mathrm{N}=9$

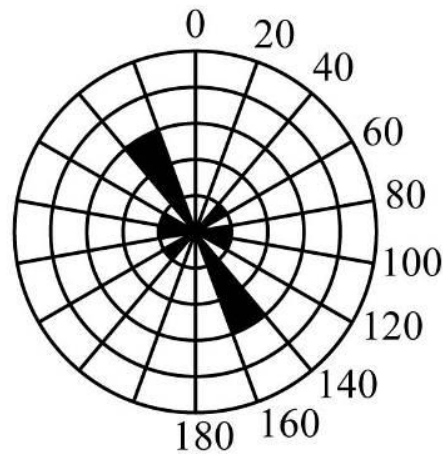

Location (13) $\mathrm{N}=8$

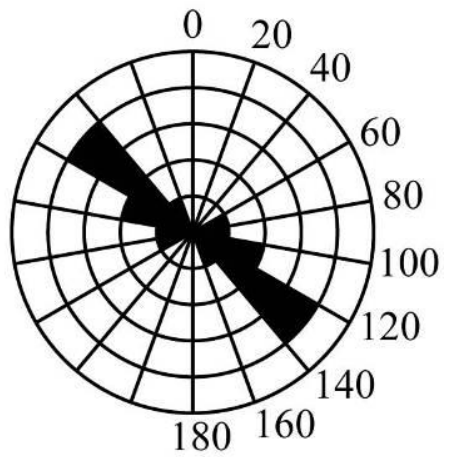

Location (11) $\mathrm{N}=9$

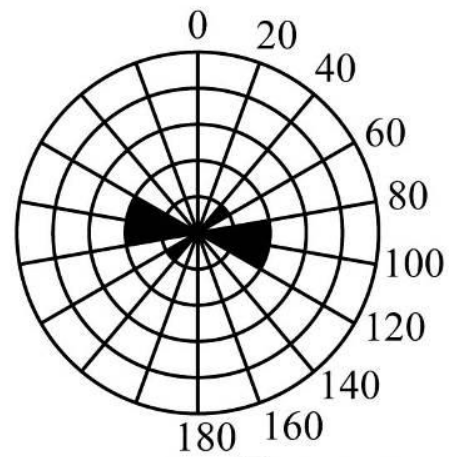

Location (14) $\mathrm{N}=5$

Figure 4. Preferred orientation of microgranitoid enclaves (Sample locations shown in Figure 2). 


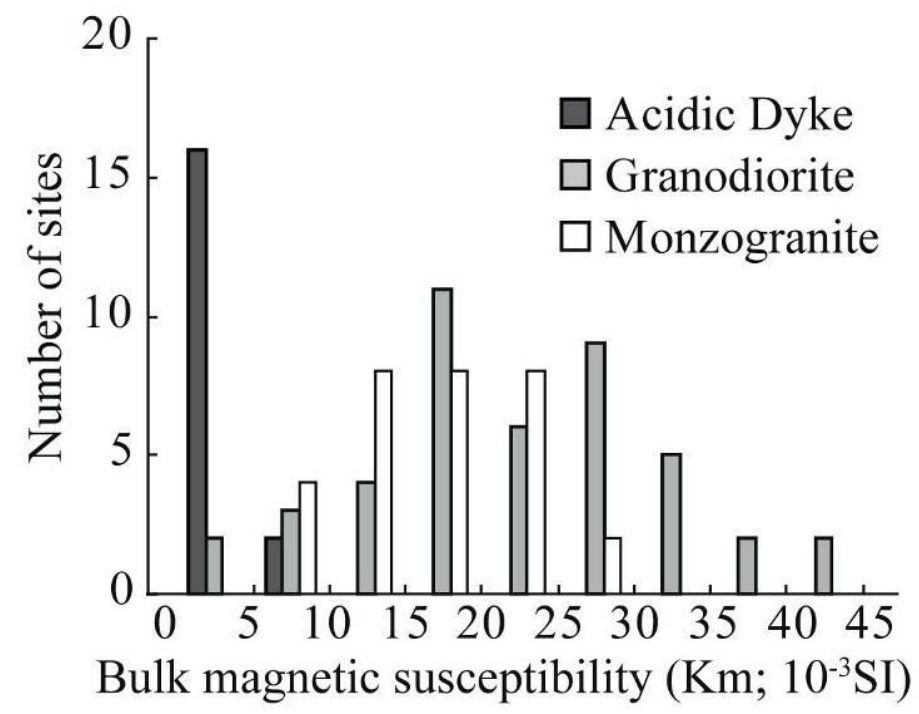

Figure 5. Distribution of bulk magnetic susceptibility of the Qingyang-Jiuhua massif. 

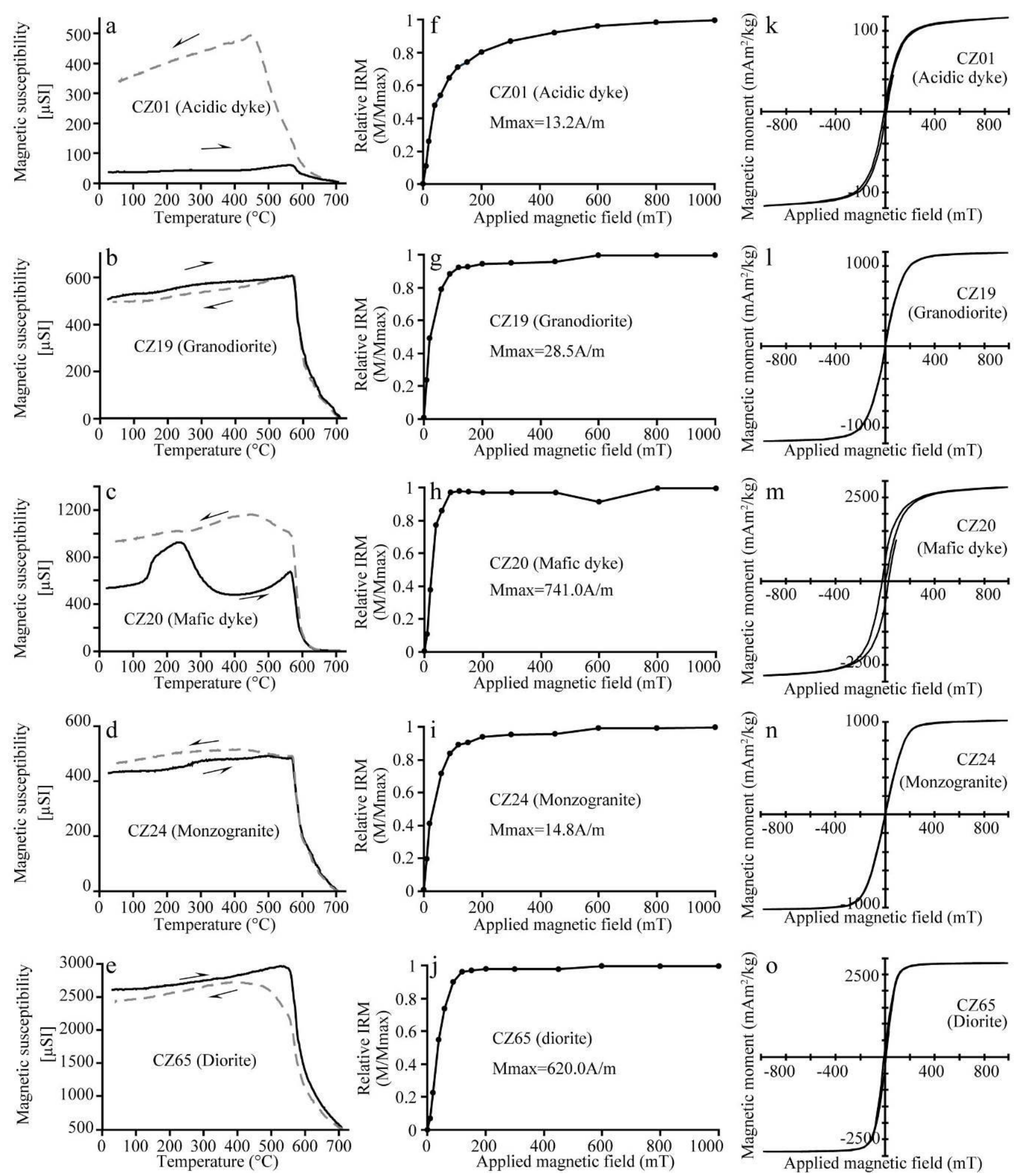

Figure 6. Thermal-Susceptibility, Isothermal Remanent Magnetization (IRM), Hysteresis Loop diagram of the Qingyang-Jiuhua massif. 


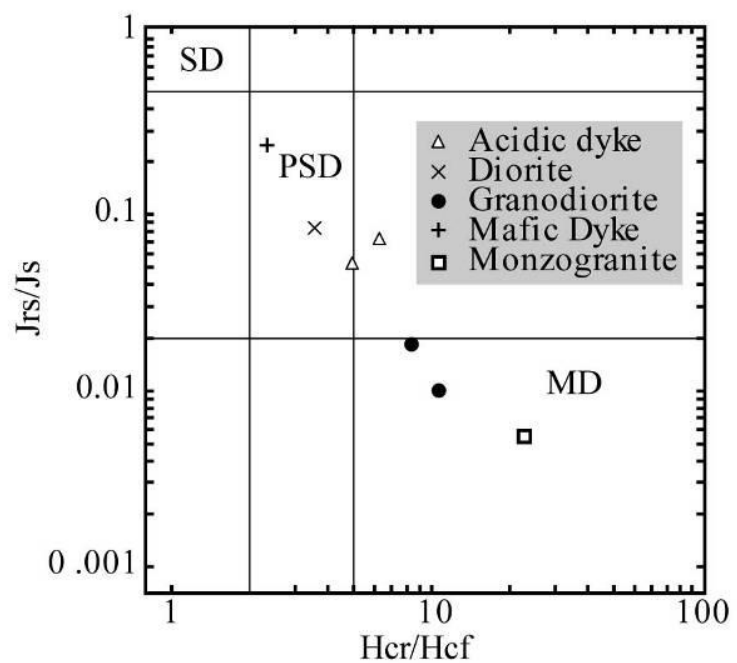

$\mathrm{Jrs} / \mathrm{Js}$ versus $\mathrm{Hcr} / \mathrm{Hc}$ for samples from the Qingyang-Jiuhua pluton, with the boundaries of SD and MD behaviours for magnetite taken from the values of Dunlop(2002)

Figure 7. Jrs/Js versus Hcr/Hc diagram from measured samples of the Qingyang-Jiuhua massif to define the magnetite size. Jrs: remanence, Js: saturation remanence, Hcr: coercivity of remanence, Hc: coercivity, SD: single domain, PSD: pseu-single domain, MD: multi-domain, respectively. 

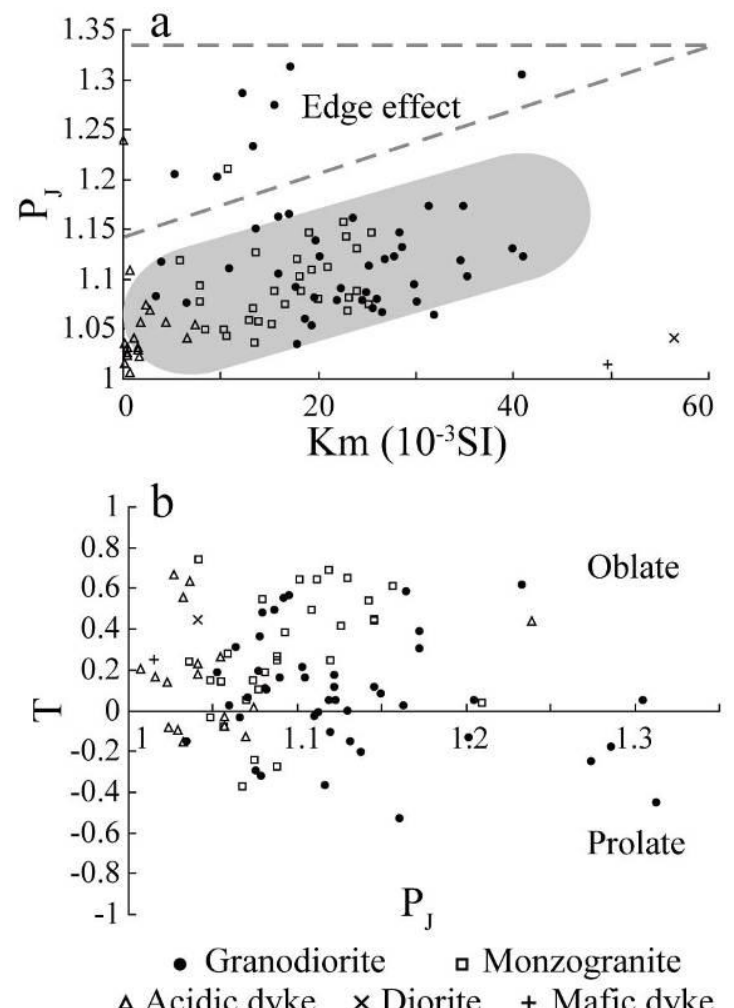

Figure 8. AMS scalar parameters of each site and main lithologies. (a) $\mathrm{T}$ (shape parameter) vs. $\mathrm{P}_{\mathrm{J}}$ (corrected anisotropy degree), (b) $\mathrm{P}_{\mathrm{J}}$ vs. $\mathrm{Km}$ (mean bulk magnetic susceptibility in $10^{-3} \mathrm{SI}$ ). The calculations of $\mathrm{T}$ and $\mathrm{P}_{\mathrm{J}}$ can be found in Jelinek (1981). 


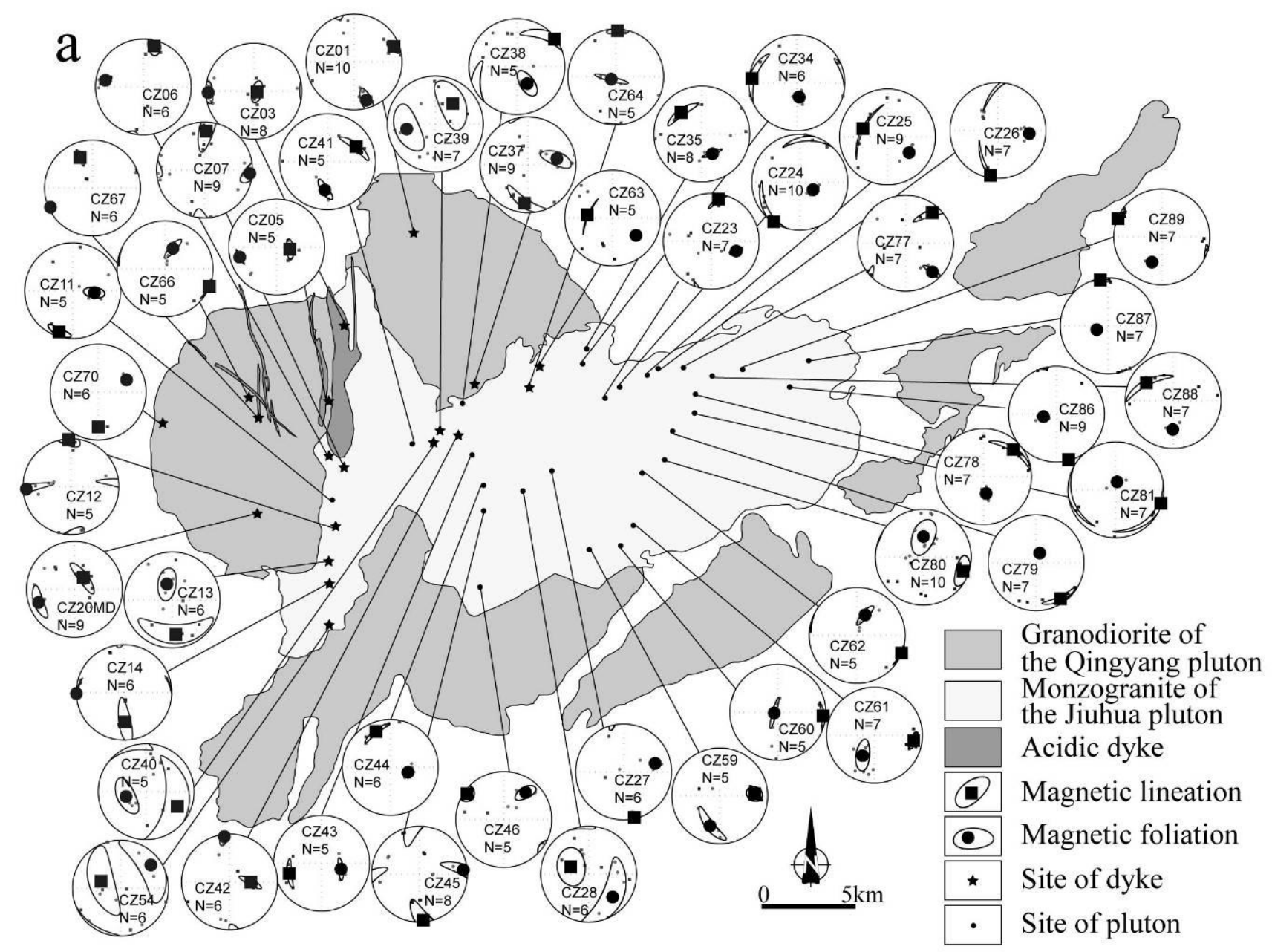

Figure $9 \mathrm{a}$ and $\mathrm{b}$ present the equal area lower hemisphere projection of each site from the dykes and the monzogranite of the Jiuhua pluton as well as the granodiorite of the Qingyang pluton respectively. Squares and circles stand for K1 (magnetic lineation) and K3 (pole of magnetic foliation), respectively. Small grey and larger black squares or circles represent individual specimen and site-mean direction, respectively with their confidence ellipses at $95 \%$ level. 


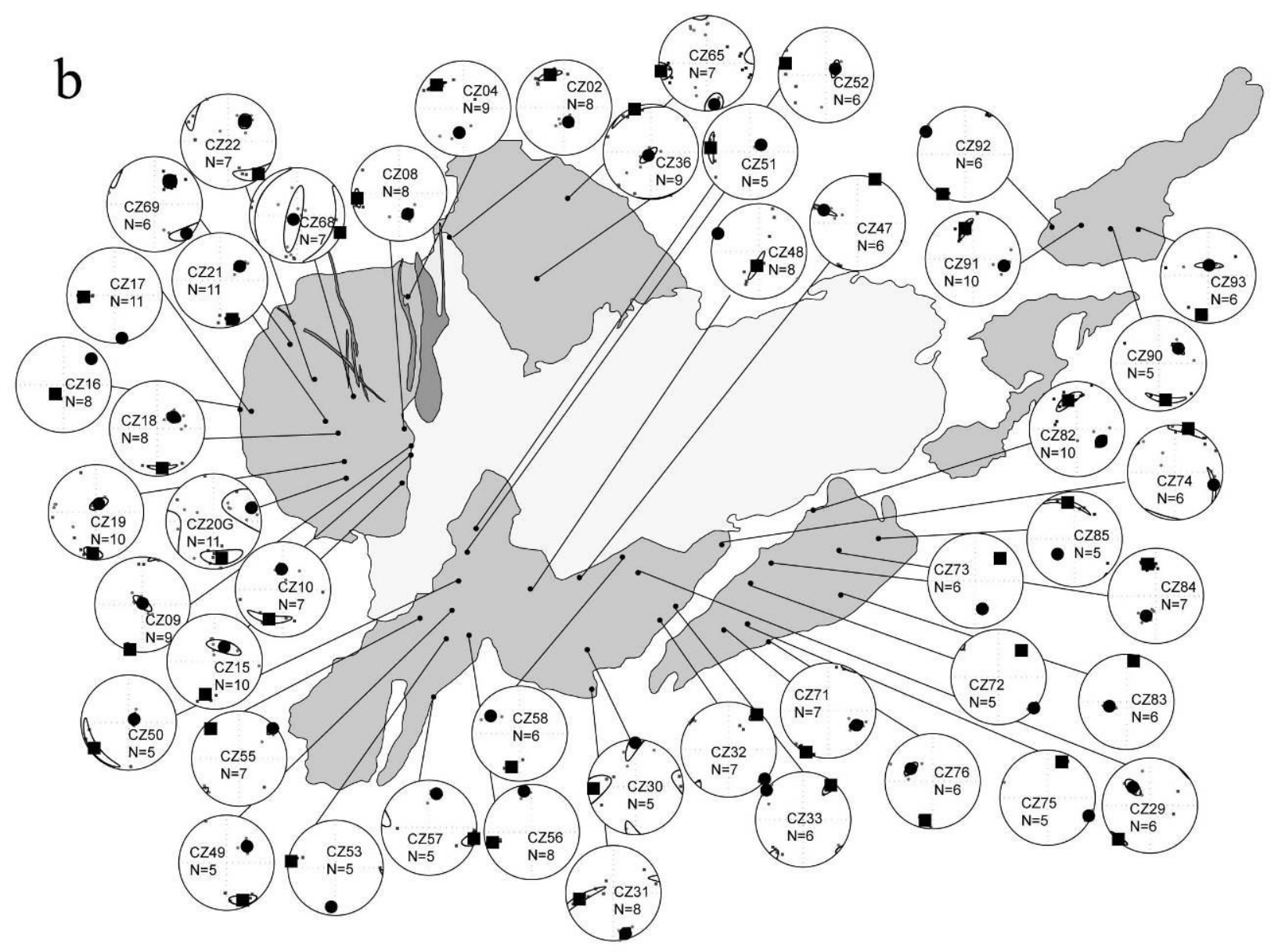

Figure $9 b$. 


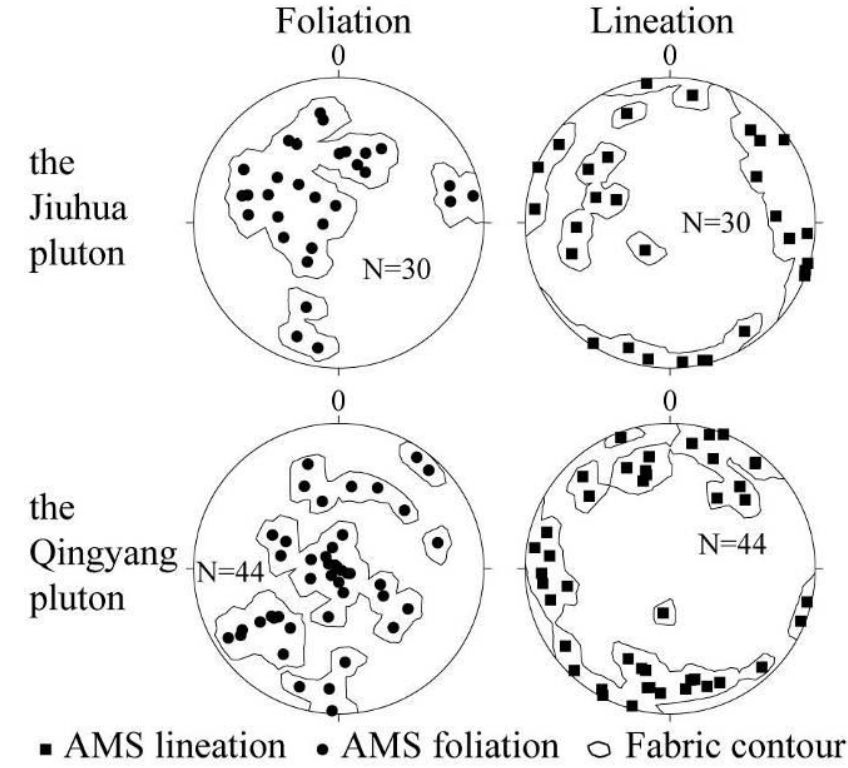

Figure 10. Total fabrics projection (equal area lower hemisphere) of the Qingyang-Jiuhua massif.

In this diagram, each solid square and circle represent one site. Data of 18 acidic dykes and 1 mafic dyke are not included in the statistics. 


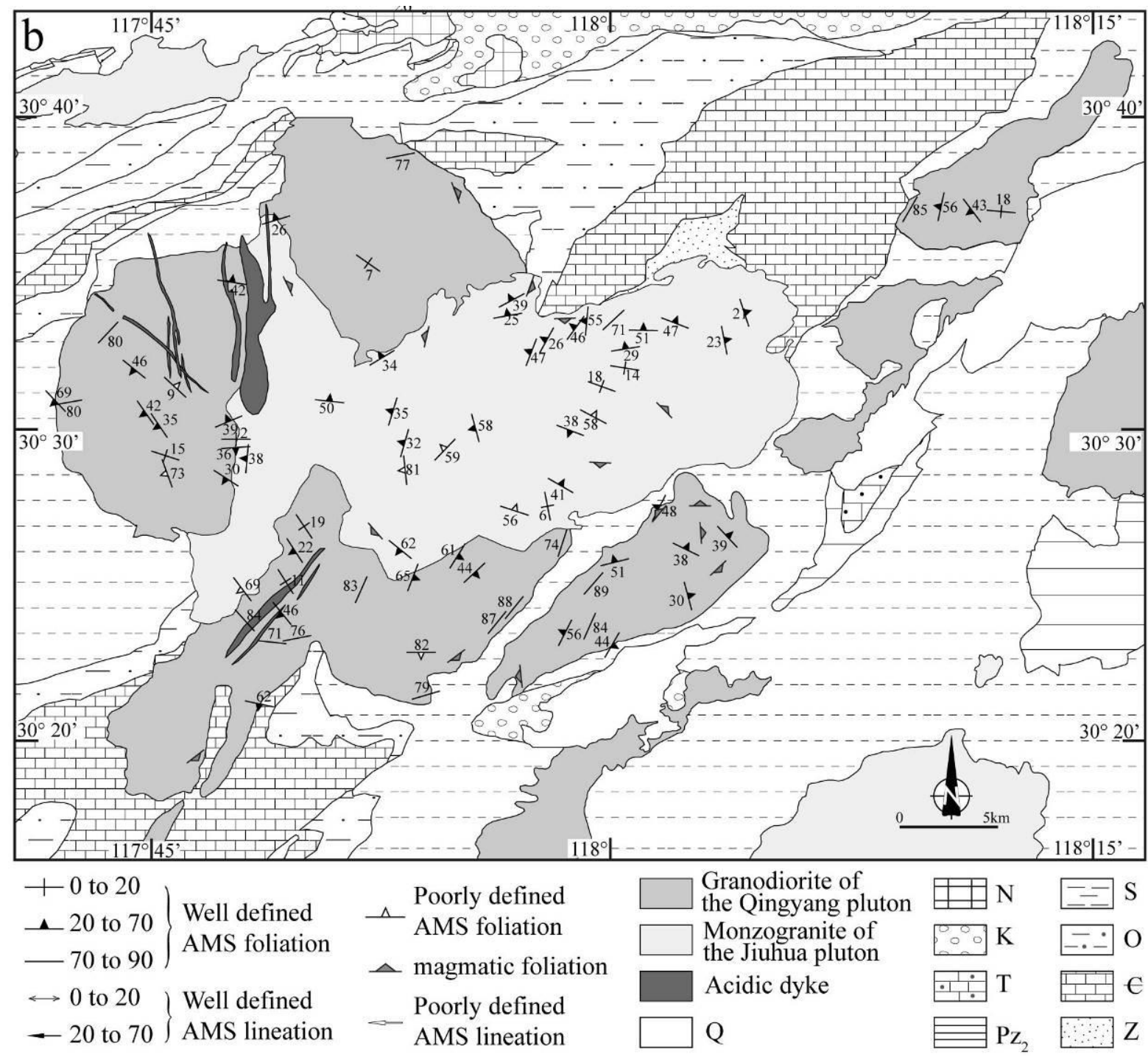

Figure 11 Magnetic foliation (a) and lineation (b) maps of the granitic rocks in the

Qingyang-Jiuhua massif. Q: Quaternary, N: Tertiary, K: Cretaceous, T: Triassic, Pz: : upper

Paleozoic, S: Silurian, O: Ordovician, $\in$ : Cambrian, Z: Sinian. 


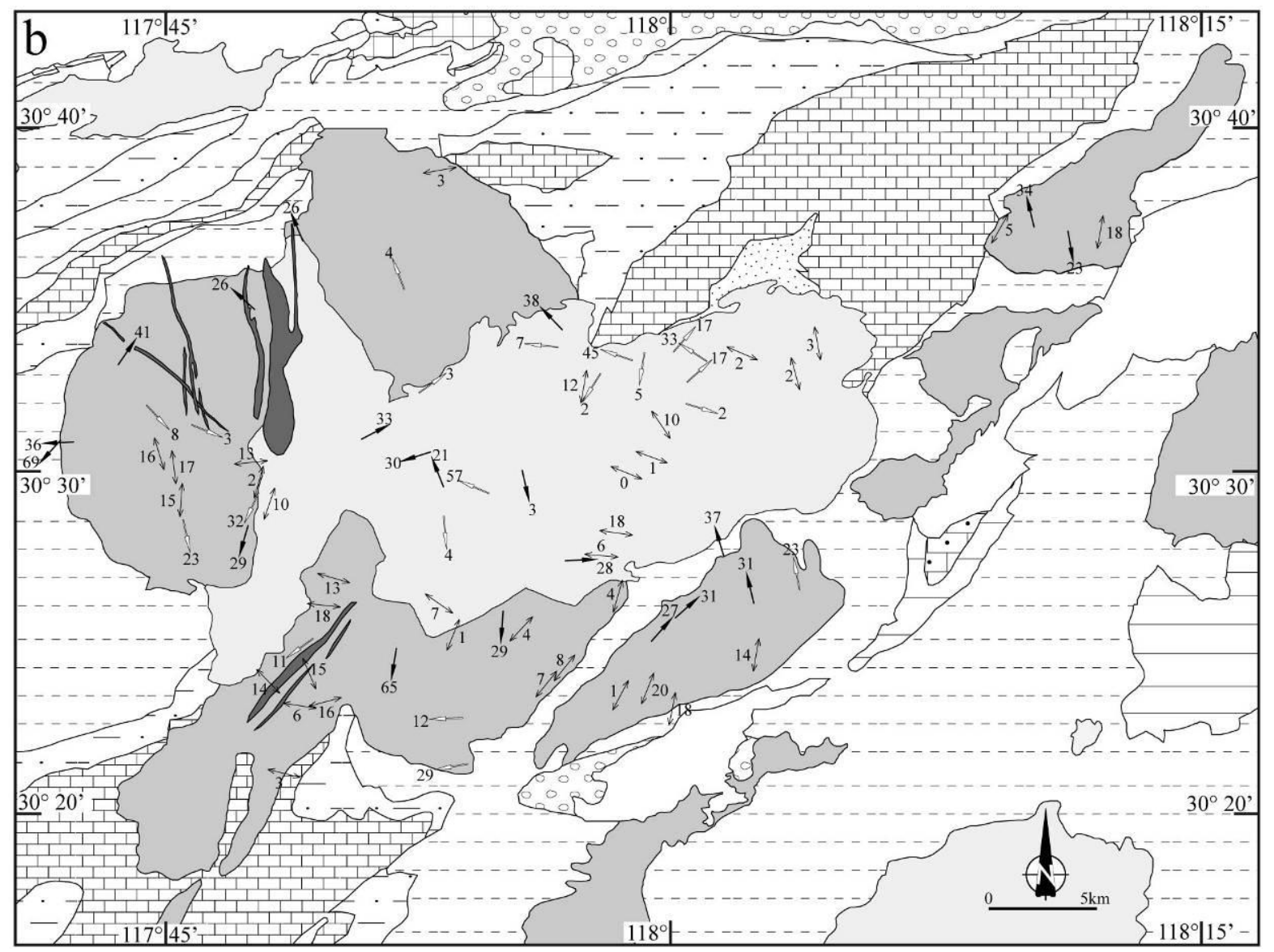

Figure $11 b$ 


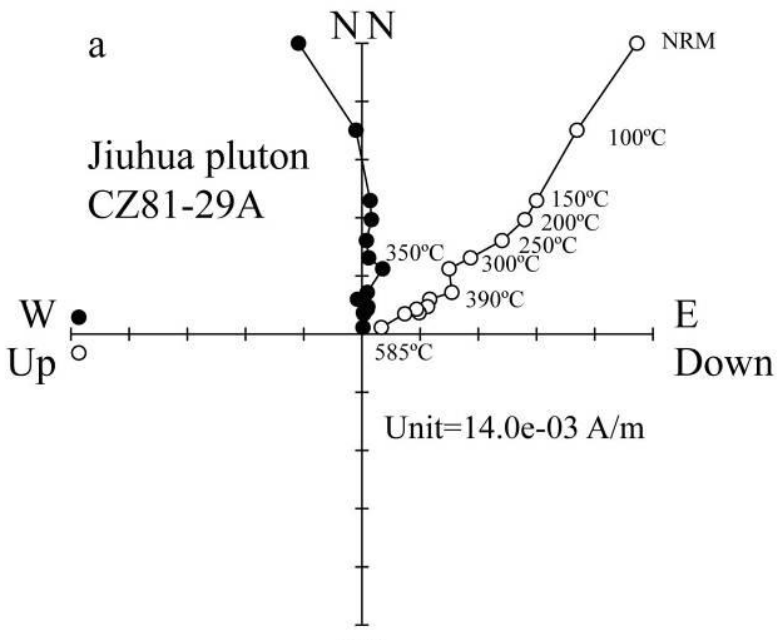

SS

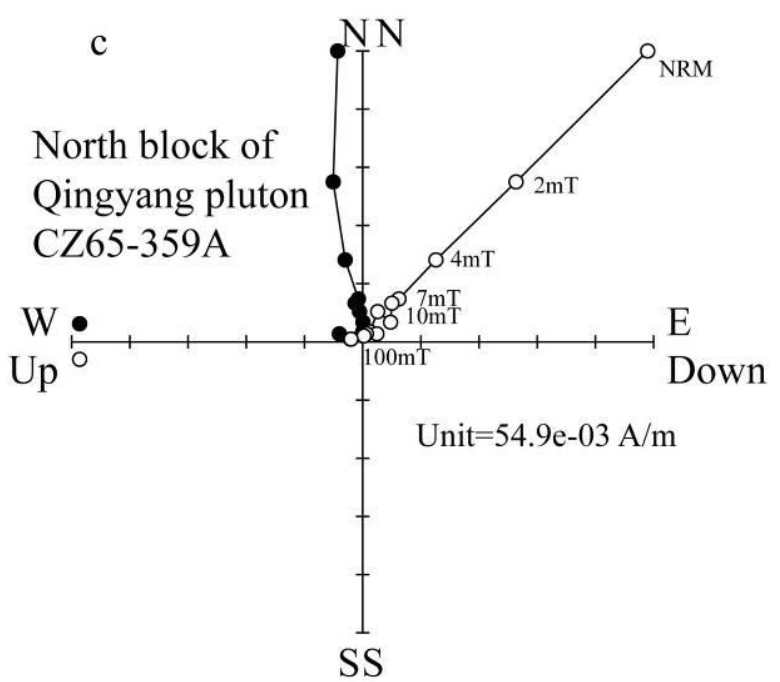

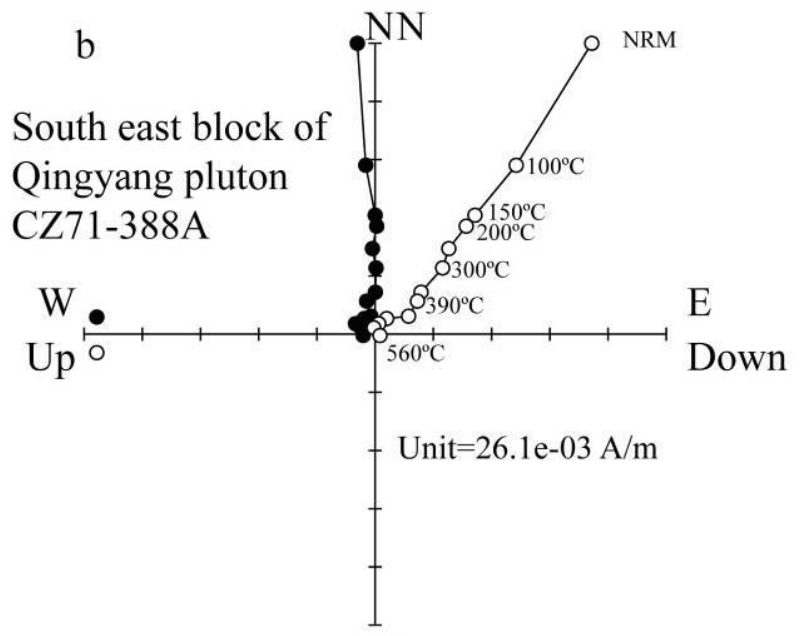

S S

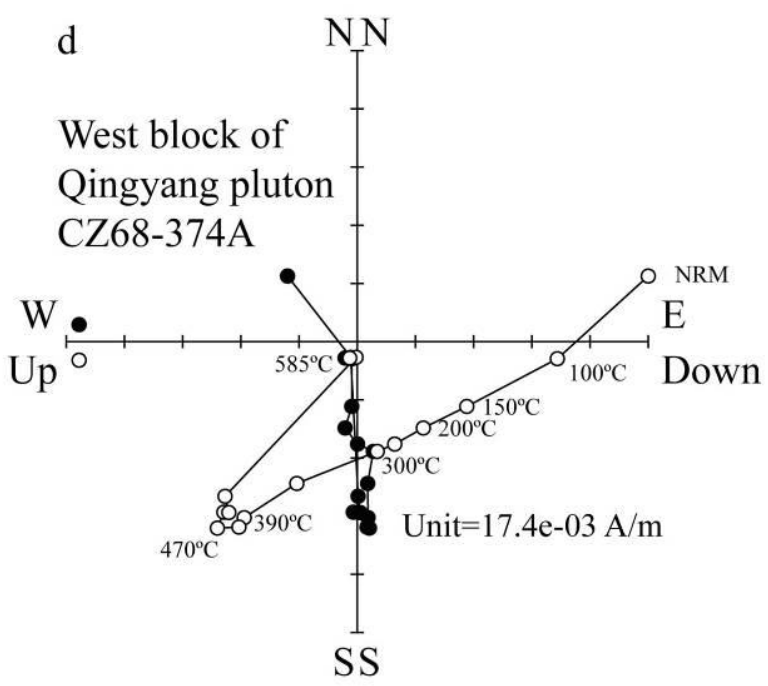

Figure 12. Zijderveld diagrams (1967) of the thermal and AF demagnetization for the representative samples of the Jiuhua pluton (CZ81-29A) and the Qingyang pluton (others). Solid and open circle stand for horizontal and vertical plan, respectively. 

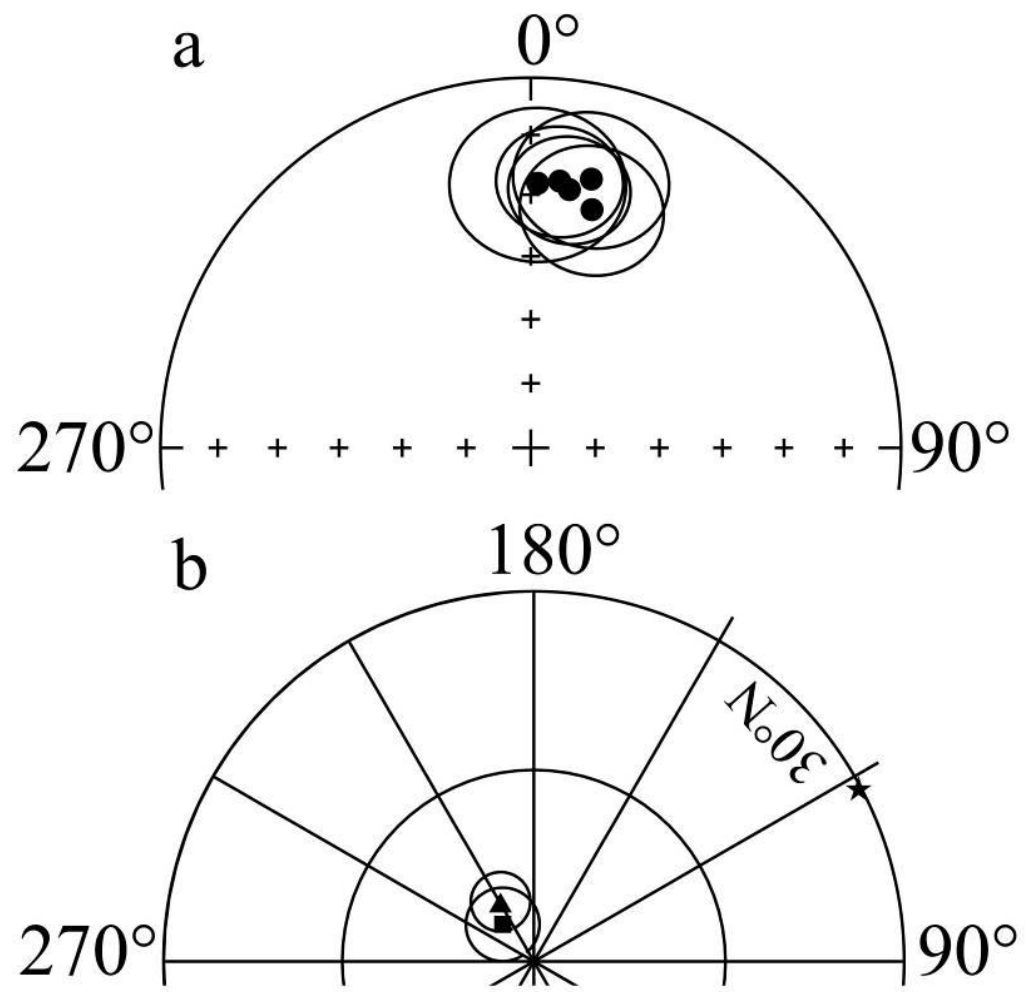

- Lower hemisphere projection of remanence of the Jiuhua pluton and blocks of the Qingyang pluton

৯ Apparent paleomagnetic pole of SCB in Cretaceous

- Apparent paleomagnetic pole of the Qingyang-Jiuhua massif in Cretaceous

O Confidence angle of apparent paleomagnetic pole $\star$ Location of the Qingyang-jiuhua massif

Figure 13. Paleomagnetic results of the Qingyang-Jiuhua massif. (a) site-mean directions of the Jiuhua and blocks of the Qingyang pluton; (b) Paleomagnetic poles for the Qingyang-Jiuhua massif (घ) and South China Block ( $\boldsymbol{\Delta}$ ) with sampling locality ( $\star$ ). 


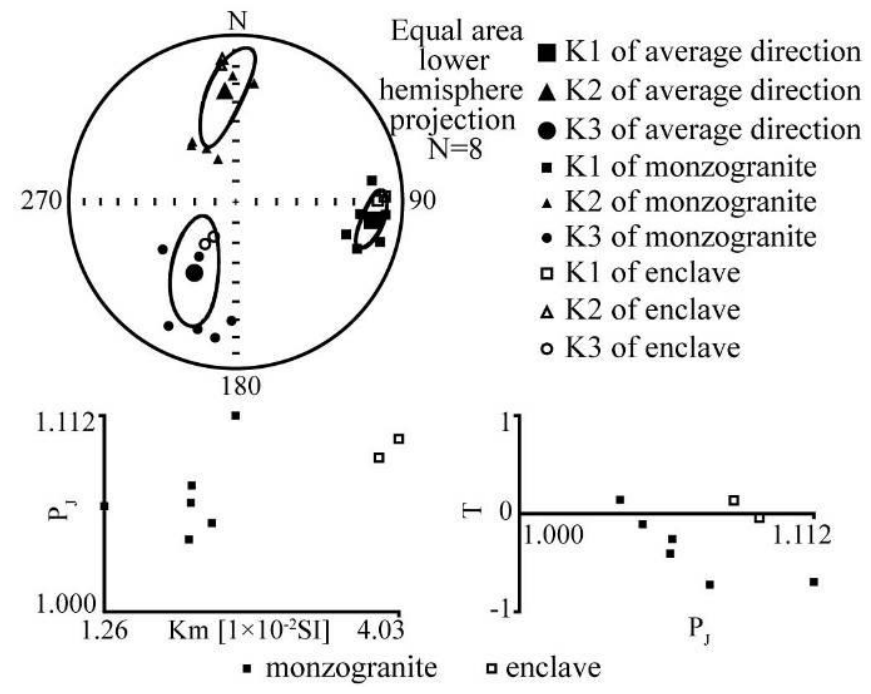

Figure 14. Comparison of AMS fabrics of the microgranitoid enclave with the host monzogranite. 


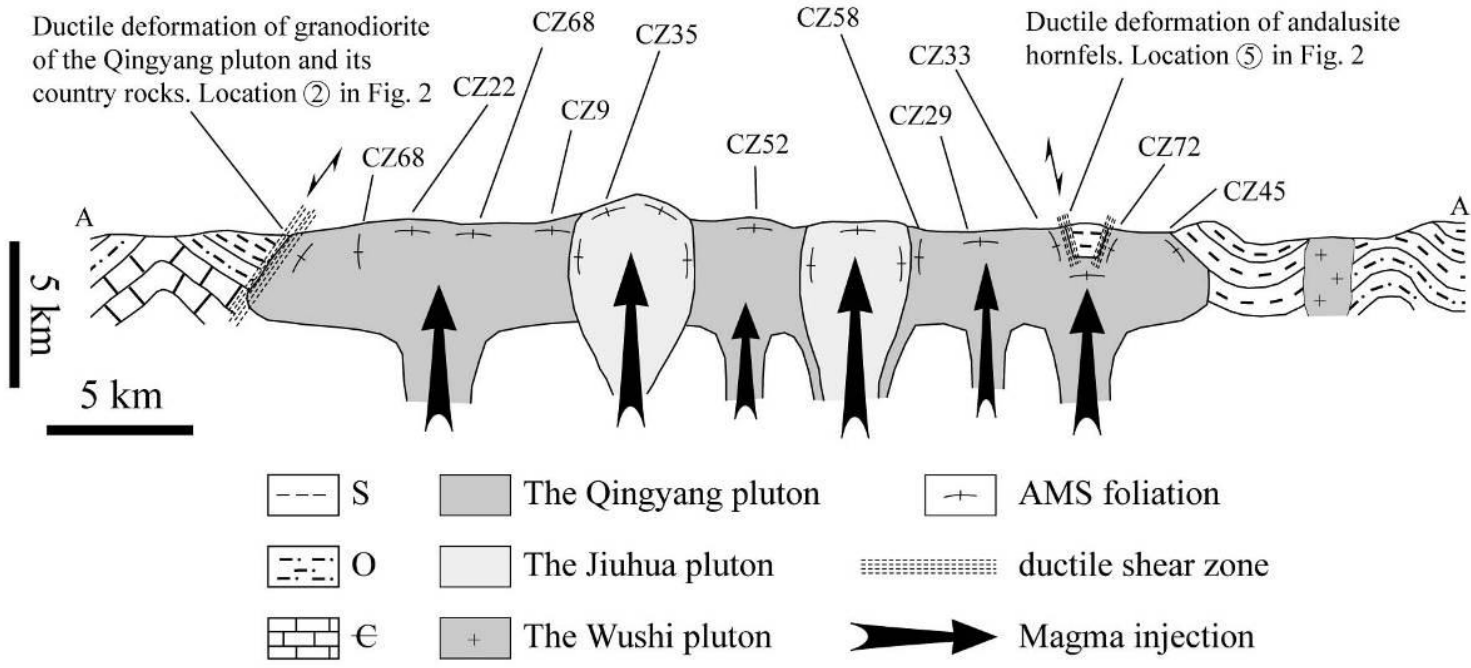

Figure 15. Emplacement model of the Qingyang-Jiuhua massif along AA' line (Fig. 2). S: Silurian, O: Ordovician, $\in$ : Cambrian, $\mathrm{CZ}$ refers to the site number shown in Figs. 9a and 9b. 
Table 1. The AMS results of granotoids from the Jiuhua-Qingyang massif.

\begin{tabular}{|c|c|c|c|c|c|c|c|c|c|c|c|c|c|c|c|}
\hline \multirow{2}{*}{ site } & \multicolumn{2}{|c|}{ Coordinates } & \multirow[b]{2}{*}{ Lith } & \multirow[b]{2}{*}{$\mathrm{n}$} & \multirow{2}{*}{$\begin{array}{c}\mathrm{Km} \\
\left(10^{-4} \mathrm{SI}\right)\end{array}$} & \multirow[b]{2}{*}{$\mathrm{P}_{\mathrm{J}}$} & \multirow[b]{2}{*}{$\mathrm{T}$} & \multicolumn{4}{|c|}{$\mathrm{K}_{1}$} & \multicolumn{4}{|c|}{$K_{3}$} \\
\hline & $\begin{array}{l}\text { Long } \\
\left({ }^{\circ} \mathrm{E}\right)\end{array}$ & $\begin{array}{l}\text { Lat } \\
\left({ }^{\circ} \mathrm{N}\right)\end{array}$ & & & & & & $\begin{array}{l}\text { Dec } \\
\left({ }^{\circ}\right)\end{array}$ & $\begin{array}{l}\text { Inc } \\
\left({ }^{\circ}\right)\end{array}$ & $\begin{array}{c}\alpha_{95 \max } \\
\left({ }^{\circ}\right)\end{array}$ & $\begin{array}{c}\alpha_{95 \min } \\
\left({ }^{\circ}\right)\end{array}$ & $\begin{array}{l}\text { Dec } \\
\left({ }^{\circ}\right)\end{array}$ & $\begin{array}{l}\text { Inc } \\
\left({ }^{\circ}\right)\end{array}$ & $\begin{array}{c}\alpha_{95 \max } \\
\left({ }^{\circ}\right)\end{array}$ & $\begin{array}{c}\alpha_{95 \min } \\
\left({ }^{\circ}\right)\end{array}$ \\
\hline CZ01 & 117.846 & 30.633 & $\mathrm{AD}$ & 10 & 15 & 1.032 & -0.151 & 68.7 & 11.9 & 13.6 & 7.3 & 162.5 & 17.3 & 24.9 & 7.1 \\
\hline CZ02 & 117.817 & 30.612 & GD & 8 & 202 & 1.122 & 0.117 & 336.6 & 25.9 & 18.2 & 5.7 & 163.5 & 63.9 & 7.7 & 5.4 \\
\hline CZ03 & 117.807 & 30.582 & $\mathrm{AD}$ & 8 & 4.74 & 1.027 & 0.665 & 102.7 & 84.5 & 19.1 & 8.7 & 268.1 & 5.4 & 14.2 & 9.6 \\
\hline CZ04 & 117.793 & 30.578 & GD & 9 & 245 & 1.078 & 0.359 & 311.6 & 26.3 & 16.5 & 2 & 188.9 & 47.6 & 8.5 & 2.2 \\
\hline CZ05 & 117.799 & 30.539 & $\mathrm{AD}$ & 5 & 7.39 & 1.007 & 0.206 & 99.7 & 67 & 17.4 & 6 & 254.8 & 21 & 12.1 & 1.9 \\
\hline CZ06 & 117.799 & 30.509 & $\mathrm{AD}$ & 6 & 73.1 & 1.054 & 0.262 & 14.9 & 12.7 & 19.1 & 8.7 & 280 & 20.9 & 13 & 4.2 \\
\hline CZ07 & 117.807 & 30.502 & $\mathrm{AD}$ & 9 & 16.9 & 1.023 & 0.14 & 2.2 & 20.3 & 39.9 & 10.1 & 94.3 & 5.9 & 21 & 9.6 \\
\hline CZ08 & 117.795 & 30.505 & GD & 8 & 257 & 1.071 & 0.063 & 263.5 & 12.6 & 12.7 & 5.8 & 157.3 & 51.3 & 10.6 & 7.3 \\
\hline CZ09 & 117.795 & 30.495 & GD & 9 & 198 & 1.138 & -0.208 & 195.5 & 2 & 12.8 & 3.3 & 2.7 & 87.9 & 19.6 & 7.1 \\
\hline CZ10 & 117.799 & 30.489 & GD & 7 & 266 & 1.066 & -0.039 & 205 & 31.9 & 35.5 & 7 & 356.1 & 54.6 & 8.9 & 7.5 \\
\hline CZ11 & 117.799 & 30.485 & MG & 5 & 134 & 1.07 & 0.05 & 198.5 & 10.2 & 17.1 & 7.7 & 94.9 & 52.5 & 19.1 & 8.4 \\
\hline CZ12 & 117.802 & 30.470 & $\mathrm{AD}$ & 5 & 3.84 & 1.024 & -0.08 & 357.2 & 1.7 & 19.4 & 10.5 & 267 & 7.8 & 53.7 & 5.1 \\
\hline CZ13 & 117.799 & 30.450 & $\mathrm{AD}$ & 6 & 10.5 & 1.041 & 0.177 & 174.1 & 28.2 & 60.3 & 18.6 & 341.6 & 61.2 & 28.8 & 15.1 \\
\hline CZ14 & 117.799 & 30.437 & $\mathrm{AD}$ & 6 & 1.16 & 1.016 & 0.167 & 178.4 & 37.8 & 44 & 9.1 & 268.6 & 0.2 & 21.9 & 1.4 \\
\hline CZ15 & 117.790 & 30.474 & GD & 10 & 219 & 1.079 & -0.324 & 195.8 & 29.3 & 10.5 & 8 & 33 & 59.6 & 30.1 & 10.3 \\
\hline CZ16 & 117.699 & 30.515 & MG & 8 & 108 & 1.21 & 0.039 & 222.4 & 69 & 4.4 & 1.8 & 46.6 & 20.9 & 5 & 1.9 \\
\hline CZ17 & 117.706 & 30.514 & MG & 11 & 106 & 1.042 & & 267.1 & 35.7 & 11.8 & 3.1 & 170.2 & 9.6 & 3.7 & 2.2 \\
\hline CZ18 & 117.754 & 30.502 & GD & 8 & 278 & 1.123 & 0.047 & 172.6 & 17.3 & 21.1 & 4.3 & 55.8 & 55.3 & 12.2 & 8.6 \\
\hline CZ19 & 117.758 & 30.486 & GD & 10 & 194 & 1.053 & 0.184 & 184.4 & 14.8 & 14.8 & 9.4 & 18.4 & 74.8 & 17 & 8.1 \\
\hline CZ20 & & & MD & 9 & 496 & 1.015 & & 36.3 & 64.8 & 32 & 8.2 & 250.1 & 21.3 & 24.4 & 9.7 \\
\hline CZ20 & 117.759 & 30.476 & GD & 11 & 179 & 1.035 & -0.15 & 167.5 & 23 & 31.2 & 14.1 & 70.2 & 16.8 & 52.3 & 27.7 \\
\hline CZ21 & 117.747 & 30.508 & GD & 11 & 268 & 1.12 & -0.106 & 162.5 & 15.7 & 10.8 & 5 & 54.6 & 47.6 & 12 & 3.4 \\
\hline CZ22 & 117.741 & 30.532 & GD & 7 & 197 & 1.081 & 0.109 & 137 & 8 & 41.1 & 11 & 39.2 & 43.9 & 13.7 & 10.3 \\
\hline CZ23 & 117.953 & 30.541 & MG & 7 & & 1.055 & & 9.9 & 12 & & 2.9 & & 43.4 & 11.9 & 5.8 \\
\hline CZ24 & 117.961 & 30.547 & MG & 10 & 182 & 1.102 & 0.639 & 212.4 & 1.6 & 61.2 & 5.7 & 119.1 & 64 & 7 & 3.1 \\
\hline CZ25 & 117.978 & 30.554 & MG & 9 & 194 & 1.109 & 0.49 & 288.6 & 45.1 & 50.3 & 1.8 & 126.1 & 43.6 & 8.2 & 3.7 \\
\hline CZ26 & 117.980 & 30.557 & MG & 7 & 79.1 & 1.077 & 0.099 & 189.2 & 5.4 & 64.7 & 2.7 & 95.4 & 34.7 & 10.3 & 3.1 \\
\hline CZ27 & 117.923 & 30.500 & MG & 6 & 84.2 & 1.049 & & 166.7 & 3 & 13.9 & 3.7 & 74.8 & 32.3 & 10.8 & 5.1 \\
\hline CZ28 & 117.907 & 30.489 & MG & 6 & 130 & 1.059 & 0.278 & 292.7 & 56.9 & 32.6 & 24.3 & 133.6 & 31.3 & 62.5 & 19.9 \\
\hline CZ29 & 117.923 & & GD & 6 & 33.9 & 1.082 & & 223.2 & 3.9 & 13.4 & 5.2 & 317.2 & 46.3 & 18.5 & 8.1 \\
\hline CZ30 & 117.894 & 30.380 & GD & 5 & & 1.06 & & 267.8 & 12.3 & 36.9 & 15.3 & 359.5 & 7.7 & 37.6 & 8.1 \\
\hline CZ31 & 117.901 & 30.357 & GD & 8 & 249 & 1.087 & 0.489 & 260.1 & 28.9 & 51.4 & 5.2 & 163.3 & 12.2 & 11.8 & 5.6 \\
\hline CZ32 & 117.937 & 30.399 & GD & 7 & 2.83 & 1.146 & 0.112 & 38.9 & 6.7 & 18.6 & 4.7 & 129.2 & 2.7 & 6.4 & 5.3 \\
\hline CZ33 & 117.942 & 30.403 & GD & 6 & 314 & 1.173 & 0.39 & 39 & 7.9 & 25.4 & 6 & 308.8 & 1.9 & 8.8 & 5.4 \\
\hline CZ34 & 117.940 & 30.560 & MG & 6 & 210 & 1.112 & 0.64 & 275.7 & 6.9 & 41 & 6.8 & 170.4 & 65.5 & 10.1 & 6.1 \\
\hline CZ35 & 117.942 & 30.568 & MG & 8 & 178 & 1.12 & 0.242 & 316.2 & 37.7 & 28.5 & 6.3 & 151.7 & 51.3 & 17.2 & 2.5 \\
\hline CZ36 & 117.866 & 30.588 & GD & 9 & 353 & 1.103 & 0.209 & 339.3 & 4.1 & 37.8 & 5.9 & 215.1 & 82.8 & 18.7 & 6.7 \\
\hline CZ37 & 117.880 & 30.549 & $\mathrm{AD}$ & 9 & 1.82 & 1.036 & 0.638 & 185.3 & 20.7 & 38.5 & 8.3 & 77.9 & 38.3 & 29.7 & 10.6 \\
\hline CZ38 & 117.873 & 30.538 & MG & 5 & 2.32 & 1.081 & 0.187 & 53.9 & 3.2 & 53.7 & 9.3 & 148.6 & 55.8 & 26.1 & 11.4 \\
\hline CZ39 & 117.861 & 30.523 & $\mathrm{AD}$ & 7 & 43.7 & 1.057 & -0.028 & 40.4 & 43.1 & 44.4 & 22.8 & 260.2 & 39.4 & 29.9 & 22.4 \\
\hline
\end{tabular}




\begin{tabular}{|c|c|c|c|c|c|c|c|c|c|c|c|c|c|c|c|}
\hline CZ40 & 117.857 & 30.516 & $\mathrm{AD}$ & 5 & 27.5 & 1.069 & -0.126 & 115.2 & 29.3 & 82.2 & 23.3 & 256.5 & 54.3 & 32 & 15.8 \\
\hline CZ41 & 117.845 & 30.515 & MG & 5 & 1.35 & 1.036 & 0.236 & 62 & 32.9 & 29.6 & 5.8 & 185.5 & 40.5 & 21 & 6 \\
\hline CD42 & 117.871 & 30.520 & $\mathrm{AD}$ & 6 & 23.4 & 1.074 & 0.019 & 90.7 & 53.5 & 22 & 4.7 & 353.5 & 5.3 & 19 & 58 \\
\hline CZ43 & 117.879 & 30.509 & MG & 5 & 156 & 1.088 & 0.266 & 252.4 & 29.8 & 22 & 4.5 & 106.6 & 55.2 & 18.4 & 4.4 \\
\hline CZ44 & 117.885 & 30.492 & MG & 6 & 240 & 1.088 & 0.242 & 338.2 & 20.5 & 23 & 4.1 & 105.6 & 58.4 & 8.5 & 4.1 \\
\hline CD45 & 117.885 & 30.478 & MG & 8 & 104 & 1.049 & -0.036 & 175.1 & 3.8 & 44.8 & 10.4 & 84.5 & 8.9 & 44.6 & 7.3 \\
\hline CZ46 & 117.883 & 30.435 & MG & 5 & 166 & 1.074 & 0.148 & 305.1 & 6.9 & 16 & 10.3 & 38.8 & 28.4 & 22.2 & 8.3 \\
\hline CZ47 & 117.890 & 30.421 & GD & 6 & 236 & 1.161 & -0.528 & 21.6 & 0.9 & 4.6 & 1.8 & 291.2 & 25.1 & 27 & 3.3 \\
\hline CZ48 & 117.862 & 30.414 & GD & 8 & 134 & 1.233 & 0.615 & 188.8 & 64.6 & 28.4 & 4.5 & 293.6 & 6.9 & 6.1 & 4.2 \\
\hline CZ49 & 117.818 & 30.402 & GD & 5 & 319 & 1.064 & 0.311 & 156.5 & 15.2 & 20.8 & 9.2 & 51.2 & 44.2 & 10.1 & 5.9 \\
\hline CZ50 & 117.822 & 30.419 & GD & 5 & 260 & 1.08 & 0.476 & 233.5 & 11 & 42 & 8.3 & 57.8 & 79 & 11.4 & 2.4 \\
\hline CZ51 & 117.827 & 30.435 & GD & 5 & 298 & 1.095 & 0.566 & 275.9 & 17.8 & 22.2 & 5.6 & 57.5 & 67.7 & 6.6 & 2.8 \\
\hline CZ52 & 117.832 & 30.448 & GD & 6 & 177 & 1.092 & 0.553 & 286.2 & 12.5 & 7.4 & 5.4 & 55.7 & 70.7 & 15.8 & 5.6 \\
\hline CZ53 & 117.815 & 30.386 & GD & 5 & 349 & 1.173 & 0.302 & 278.5 & 6.4 & 14.8 & 2.7 & 186.4 & 18.8 & 4.1 & 2.7 \\
\hline CZ54 & 117.799 & 30.414 & $\mathrm{AD}$ & 6 & 15.6 & 1.029 & -0.095 & 289.6 & 54.4 & 63.7 & 21.8 & 52.7 & 21.3 & 55.9 & 24.2 \\
\hline CZ55 & 117.800 & 30.398 & GD & 7 & 400 & 1.13 & -0.005 & 316.4 & 13.9 & 8.5 & 3.7 & 47.8 & 5.8 & 17 & 4.1 \\
\hline CZ56 & 117.828 & 30.388 & GD & 8 & 286 & 1.132 & -0.156 & 255.2 & 16.1 & 9.6 & 2 & 349.2 & 13.7 & 8.2 & 3.8 \\
\hline CZ57 & 117.808 & 30.353 & GD & 5 & 65 & 1.076 & -0.294 & 103.9 & 3.2 & 25.1 & 8.6 & 12.2 & 27.9 & 9.2 & 3.1 \\
\hline CZ58 & 117.911 & 30.435 & GD & 6 & 252 & 1.113 & -0.01 & 193.6 & 28.6 & 8.9 & 2.9 & 301.5 & 29.5 & 8.2 & 2.4 \\
\hline CZ59 & 117.944 & 30.457 & MG & 5 & 139 & 1.057 & -0.081 & 86.7 & 27.8 & 15.7 & 10.5 & 197.9 & 34.4 & 35.5 & 7.4 \\
\hline CZ60 & 117.961 & 30.459 & MG & 5 & 231 & 1.068 & -0.375 & 94.6 & 6 & 19 & 2.8 & 258.8 & 83.8 & 27.4 & 3.4 \\
\hline CZ61 & 117.969 & 30.470 & MG & 8 & 252 & 1.075 & -0.244 & 97.6 & 18.3 & 12.9 & 6.2 & 210.1 & 49.2 & 28.6 & 11 \\
\hline CZ62 & 117.974 & 30.499 & MG & 5 & 183 & 1.088 & -0.275 & 111.6 & 0.4 & 18.3 & 1.5 & 21.1 & 52.3 & 22.1 & 5.1 \\
\hline CZ63 & 117.916 & 30.559 & $\mathrm{AD}$ & 5 & 0.33 & 1.239 & 0.438 & 275.2 & 46.9 & 31.6 & 1 & 127.7 & 38.3 & 3 & 5 \\
\hline CZ64 & 117.911 & 30.547 & $\mathrm{AD}$ & 5 & 17.4 & 1.057 & -0.073 & 2.2 & 4 & 13.7 & 6.9 & 244 & 81.5 & 29.8 & 4 \\
\hline CZ65 & 117.883 & 30.646 & DIO & 11 & 564 & 1.041 & 0.448 & 260 & 3.1 & 23.7 & 10.9 & 169.3 & 13.1 & 22.5 & 12 \\
\hline CZ66 & 117.754 & 30.541 & $\mathrm{AD}$ & 6 & 65.6 & 1.041 & 0.232 & 129.7 & 61.2 & 31.9 & 5.7 & 243.6 & 12.5 & 19 & 5.4 \\
\hline CD67 & 117.760 & 30.530 & $\mathrm{AD}$ & 6 & 4.13 & 1.032 & 0.56 & 337.9 & 31.8 & 17.6 & 2.4 & 245.4 & 4.1 & 7.4 & 2.6 \\
\hline CZ68 & 117.763 & 30.522 & GD & 7 & 96.8 & 1.202 & -0.134 & 111.9 & 3.3 & 61.1 & 18.3 & 222.6 & 80.8 & 60.6 & 13 \\
\hline CZ69 & 117.727 & 30.551 & GD & 6 & 223 & 1.09 & 0.161 & 33.8 & 41.4 & 12.9 & 11.1 & 132.6 & 9.8 & 27.9 & 11 \\
\hline CZ70 & 117.706 & 30.527 & $\mathrm{AD}$ & 6 & 6.22 & 1.109 & 0.413 & 179.6 & 28.3 & 8.1 & 3 & 66.9 & 35.7 & 7.5 & 3.2 \\
\hline CZ71 & 117.971 & 30.391 & GD & 7 & 137 & 1.15 & 0.081 & 208 & 1.4 & 12.2 & 6.6 & 117.1 & 33.6 & 12.4 & 6.9 \\
\hline CZ72 & 117.986 & 30.417 & GD & 5 & 172 & 1.313 & -0.456 & 40.5 & 27 & 4.5 & 2.8 & 131.2 & 1.5 & 8.2 & 4.4 \\
\hline CZ73 & 117.997 & 30.429 & GD & 6 & 156 & 1.274 & -0.253 & 47.5 & 30.5 & 6 & 3.6 & 166.3 & 39.2 & 5.4 & 3.7 \\
\hline CZ74 & 117.970 & 30.439 & GD & 6 & 159 & 1.105 & 0.157 & 16.4 & 4.4 & 25.4 & 11.2 & 107.7 & 16.3 & 28.8 & 3.4 \\
\hline CZ75 & 117.984 & 30.395 & GD & 5 & 123 & 1.286 & -0.182 & 21.5 & 19.8 & 6.1 & 2.8 & 113.7 & 6.2 & 8.6 & 2.6 \\
\hline CZ76 & 117.996 & 30.384 & GD & 6 & 39 & 1.117 & -0.368 & 190.9 & 17.6 & 10.9 & 3.2 & 300.1 & 46 & 13.4 & 7.3 \\
\hline CZ77 & 30.558 & 117.997 & MG & 7 & 191 & 1.146 & 0.446 & 41 & 16.6 & 38.4 & 4.7 & 137 & 19.4 & 20.6 & 3.4 \\
\hline CZ78 & 30.543 & 118.003 & MG & 7 & 58.3 & 1.119 & 0.69 & 47.6 & 17.3 & 37.4 & 4.5 & 171.3 & 60.8 & 9.5 & 2.9 \\
\hline CZ79 & 30.523 & 117.990 & MG & 7 & 240 & 1.13 & 0.648 & 145.7 & 10.4 & 25.8 & 5 & 20.2 & 72.4 & 5 & 3 \\
\hline CZ80 & 30.507 & 117.986 & MG & 10 & 201 & 1.08 & 0.542 & 109.6 & 1.32 & 21.2 & 14.5 & 208.1 & 32.2 & 33.4 & 18 \\
\hline CZ81 & 30.533 & 118.003 & MG & 7 & 79 & 1.093 & 0.384 & 106.5 & 1.7 & 77.4 & 4.9 & 9.5 & 76.4 & 8.5 & 2.6 \\
\hline CZ82 & 30.458 & 118.021 & GD & 10 & 53.4 & 1.205 & 0.052 & 343 & 37.1 & 24.5 & 8.6 & 116.6 & 42.4 & 10.9 & 9 \\
\hline CZ83 & 30.411 & 118.037 & GD & 6 & 159 & 1.163 & 0.025 & 9.9 & 13.6 & 3.1 & 1.6 & 255.4 & 59.7 & 8.3 & 3 \\
\hline CZ84 & 30.436 & 118.035 & GD & 7 & 109 & 1.11 & -0.03 & 346 & 31.4 & 12.5 & 6.4 & 205.7 & 51.6 & 10.2 & 7.1 \\
\hline
\end{tabular}




\begin{tabular}{|c|c|c|c|c|c|c|c|c|c|c|c|c|c|c|c|}
\hline CZ85 & 30.442 & 118.058 & GD & 5 & 171 & 1.165 & 0.585 & 349.4 & 22.8 & 40.6 & 3.7 & 228.6 & 50.6 & 4.6 & 3.8 \\
\hline CZ86 & 30.547 & 118.056 & MG & 9 & 255 & 1.146 & 0.438 & 165.1 & 1.8 & 6.1 & 4.1 & 259.4 & 67.4 & 7.5 & 4.1 \\
\hline CZ87 & 30.562 & 118.066 & MG & 7 & 227 & 1.157 & 0.612 & 350.4 & 3.2 & 14.2 & 2.6 & 251.7 & 69.5 & 3.5 & 2.5 \\
\hline CZ88 & 30.553 & 118.013 & MG & 7 & 229 & 1.143 & 0.538 & 303.2 & 33.2 & 44.8 & 4.9 & 180.7 & 39.3 & 8.1 & 5.9 \\
\hline CZ89 & 30.557 & 118.030 & MG & 7 & 136 & 1.126 & 0.413 & 292.7 & 1.6 & 15 & 3.9 & 201.2 & 42.7 & 5.5 & .7 \\
\hline CZ90 & 30.616 & 118.188 & GD & 5 & 347 & 1.119 & 0.046 & 169.5 & 22.9 & 31.3 & 5.5 & 52.8 & 46.8 & 12.8 & 4 \\
\hline CZ91 & 30.618 & 118.171 & GD & 10 & 411 & 1.122 & 0.171 & 345.8 & 33.9 & 21.5 & 5.6 & 102.5 & 33.7 & 9.9 & 8 \\
\hline CZ92 & 30.618 & 118.153 & GD & 6 & 409 & 1.305 & 0.052 & 209.5 & 4.8 & 9.2 & 5.3 & 300 & 5.5 & 6.7 & .8 \\
\hline CZ93 & 30.616 & 118.204 & GD & 6 & 302 & 1.077 & 0.19 & 189.8 & 17.9 & 8.7 & 5.7 & 4.6 & 72 & 24 & \\
\hline
\end{tabular}

Lat: latitude, long: Longitude, lith: lithology, km: mean magnetic susceptibility, $\mathrm{P}_{\mathrm{J}}$ and $\mathrm{T}$ :

anisotropy degree and shape parameter, respectively, K1 and K3: magnetic lineation and pole of magnetic foliation, respectively, Inc: inclination, Dec: declination, $\alpha_{95} \max$ and $\alpha_{95} \min$ : long and short axis of ellipsoid uncertainty, respectively, GD: granoodiorite, MG: monzogranite, DIO: diorite, AD: acidic dyke, symbols of *,' and \#: microgranitic, quartzose and pegmatitic dyke, respectively.

Table 2. Paleomagnetic results of high temperature magnetic components from the Qingyan g-Jiuhua massif

\begin{tabular}{|c|c|c|c|c|c|c|c|c|c|c|c|c|}
\hline \multirow{2}{*}{ Subpluton } & \multicolumn{2}{|c|}{ Coordinates } & $\mathrm{N}$ & $\mathrm{P}$ & \multicolumn{4}{|c|}{ Direction } & \multicolumn{4}{c|}{ Pole } \\
\cline { 2 - 14 } & $\begin{array}{c}\text { Lat. } \\
\left({ }^{\circ} \mathrm{N}\right)\end{array}$ & $\begin{array}{c}\text { Long. } \\
\left({ }^{\circ} \mathrm{E}\right)\end{array}$ & & & $\begin{array}{c}\mathrm{D} \\
\left({ }^{\circ}\right)\end{array}$ & $\begin{array}{c}\mathrm{I} \\
\left({ }^{\circ}\right)\end{array}$ & $\mathrm{k}$ & $\begin{array}{c}\alpha_{95} \\
\left({ }^{\circ}\right)\end{array}$ & $\begin{array}{c}\lambda \\
\left({ }^{\circ}\right)\end{array}$ & $\begin{array}{c}\phi \\
\left({ }^{\circ}\right)\end{array}$ & $\begin{array}{c}\mathrm{dp} \\
\left({ }^{\circ}\right)\end{array}$ & $\begin{array}{c}\mathrm{dm} \\
\left({ }^{\circ}\right)\end{array}$ \\
\hline $\mathrm{W}$ & 30.5 & 117.7 & 10 & $\mathrm{~N}$ and R & 6.2 & 43.2 & 17.3 & 11.3 & 82.3 & 250.5 & 8.7 & 14.0 \\
\hline $\mathrm{S}$ & 30.4 & 117.9 & 11 & $\mathrm{~N}$ and R & 12.7 & 46.3 & 19.3 & 11.3 & 78.6 & 218.1 & 9.3 & 14.5 \\
\hline $\mathrm{N}$ & 30.6 & 117.9 & 8 & $\mathrm{~N}$ & 358.2 & 47.4 & 17.8 & 14.7 & 87.4 & 335.5 & 12.4 & 19.1 \\
\hline $\mathrm{SE}$ & 30.4 & 118.0 & 12 & $\mathrm{~N}$ & 11.4 & 49.4 & 22.3 & 9.0 & 80.2 & 205.9 & 7.9 & 11.9 \\
\hline $\mathrm{J}$ & 30.5 & 117.9 & 14 & $\mathrm{~N}$ & 13.5 & 50.2 & 23.6 & 8.1 & 78.4 & 202.1 & 7.3 & 10.9 \\
\hline Average & $\mathbf{3 0 . 5}$ & $\mathbf{1 1 7 . 9}$ & 5 & & $\mathbf{8 . 3}$ & $\mathbf{4 7 . 4}$ & $\mathbf{2 5 1 . 4}$ & $\mathbf{4 . 8}$ & $\mathbf{8 2 . 5}$ & $\mathbf{2 2 0 . 1}$ & $\mathbf{A}_{\mathbf{9 5}}=\mathbf{5 . 7}^{\circ}$ \\
\hline SCB & & & & & & & & & $\mathbf{7 9 . 4}$ & $\mathbf{2 0 9 . 0}$ & $\mathbf{A}_{\mathbf{9 5}}=\mathbf{4 . 6}^{\circ}$ \\
\hline
\end{tabular}

$\mathrm{N}$ : specimen number, D: declination, I: inclination, k: precision parameter, $\alpha_{95}$ and $\mathrm{A}_{95}$ : statistic confidence of paleomagnetic direction and paleomagnetic pole at $95 \%$ level, respectively, $\lambda, \phi, d p$ 
and dm: latitude and longitude of paleomagnetic pole and its half radius of confidence in latitude and longitude, respectively, J: the Jiuhua pluton, W, S, N, SE: west, south, north, southeast subpluton of the Qingyang pluton. 